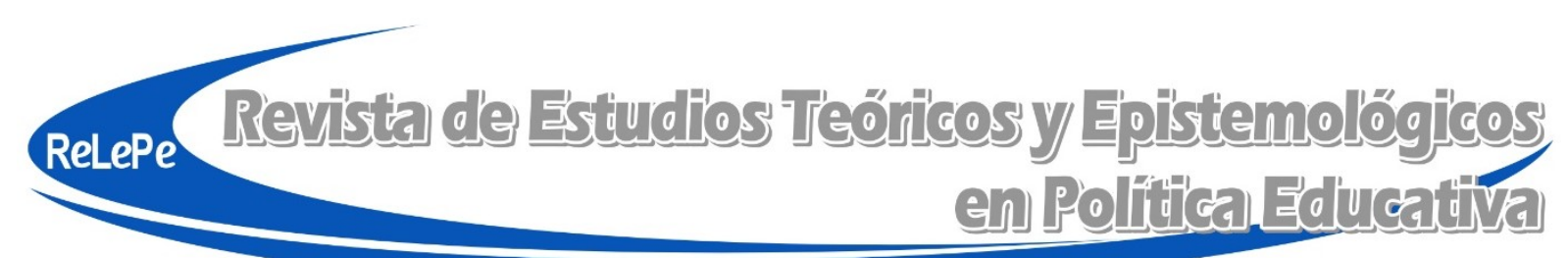

ISSN 2409-3696

doi https://doi.org/10.5212/retepe.v.6.18101.003

\title{
A produção de conhecimento sobre a Base Nacional Comum Curricular no Brasil: levantamento de teses, dissertações e artigos
}

\section{The production of knowledge about the National Common Curricular Base in Brazil: survey of thesis, dissertations and articles}

\section{La producción de conocimiento sobre la Base Nacional Común Curricular en Brasil: recopilación bibliográfica de tesis, disertaciones y artículos}

\author{
Paulo Fioravante Giareta* \\ (iD) https://orcid.org/0000-0002-0649-4756
}

\begin{abstract}
Resumo: O objetivo deste texto é apresentar um levantamento de artigos, teses e dissertações sobre a Base Nacional Comum Curricular (BNCC). O levantamento inclui 501 artigos e 101 teses e dissertações. Ele indica a possibilidade de organizar as publicações em 20 categorias e explicita a centralidade da produção de conhecimento sobre a BNCC como política curricular, seguida de sua relação com a Língua Portuguesa e a Matemática. As produções sobre a BNCC indicam uma ampla capacidade de diálogo com as políticas de formação de professores, políticas de avaliação e políticas de gestão da educação e com as etapas da Educação Básica. Há, ainda, a ausência parcial ou total de produções sobre campos e temáticas como Educação em Direitos Humanos, Educação Inclusiva e Educação para Relações Étnico-Raciais.

Palavras-chave: Política educacional. BNCC. Produção de conhecimento.
\end{abstract}

Abstract: The objective of this text is to present a survey of articles, theses and dissertations on the National Common Curriculum Base (Base Nacional Comum Curricular - BNCC). The survey includes 501 articles and 101 theses and dissertations. It indicates the possibility of organizing publications into 20 categories and explains the centrality of the production of knowledge about the BNCC as a curriculum policy, followed by its relationship with the Portuguese Language and Mathematics. The productions on the BNCC indicate a wide capacity for dialogue with teacher training policies, evaluation policies and education management policies and with the stages of Basic Education. There is also a partial or total absence of productions on fields and themes such as Human Rights Education, Inclusive Education and Education for Ethnic-Racial Relations.

Keywords: Education policies. BNCC. Knowledge production.

Resumen: El objetivo de este texto es presentar una recopilación de artículos, tesis y disertaciones sobre la Base Nacional Común Curricular (BNCC). La recopilación incluye 501 artículos y 101 tesis y disertaciones. Ella indica la posibilidad de organizar las publicaciones en veinte categorías y explica la centralidad de la producción de conocimiento sobre la BNCC como política curricular, seguida de su relación con la Lengua Portuguesa y la Matemática. Las producciones sobre la BNCC indican una amplia capacidad de diálogo con

\footnotetext{
* Pós-doutorando no Programa de Pós-Graduação em Educação da Universidade Estadual de Ponta Grossa (UEPG). Professor da Universidade Federal de Mato Grosso do Sul (UFMS), campus de Três Lagoas (CPTL). E-mail: <pfgiareta27@yahoo.com.br>.
}

Revista de Estudios Teóricos y Epistemológicos en Política Educativa, v. 6, e2118101, p. 1-38, 2021 Disponible en: $<$ https://www.revistas2.uepg.br/index.php/retepe $>$ 
A produção de conhecimento sobre a Base Nacional Comum Curricular no Brasil: levantamento...

las políticas de formación docente, políticas de evaluación y políticas de gestión de la educación y con las etapas de la Educación Primaria. Hay, aún, ausencia total o parcial de producciones sobre campos y temáticas como Educación en Derechos Humanos, Educación Inclusiva y Educación para las Relaciones Étnico-raciales.

Palabras clave: Política educativa. BNCC. Producción de conocimiento.

\section{Introdução}

Este texto tem por objetivo apresentar um levantamento de pesquisas e publicações brasileiras sobre a Base Nacional Comum Curricular (BNCC), do período de 2014 a 2020, que inclui artigos em periódicos, teses e dissertações. O levantamento está vinculado a um projeto de pesquisa mais amplo do Programa de Pós-Graduação em Educação da Universidade Estadual de Ponta Grossa (UEPG), que objetiva realizar uma metapesquisa com uma amostra de pesquisas sobre a BNCC.

A BNCC foi formalizada com a homologação, pelo Conselho Nacional de Educação (CNE), da Resolução N No 2, de 22 de dezembro de 2017, que institui e orienta a implantação da Base Nacional Comum Curricular, no âmbito da política educacional brasileira (BRASIL, 2017). Essa Resolução foi complementada, em 17 de dezembro de 2018, pela Resolução No 4 (BRASIL, 2018), que institui a Base Nacional Comum Curricular na etapa do Ensino Médio (BNCC-EM).

As referidas Resoluções apresentam-se como resultado de profundas disputas políticopedagógicas que remontam os movimentos pela redemocratização brasileira na década de 1980, como ampliação das relações institucionais e atendimento às demandas das relações produtivas, conferindo centralidade, no contexto das políticas educacionais, às políticas curriculares. Essas disputas expressam-se no próprio processo de elaboração da BNCC, demandando constantes movimentos de formulações e reformulações, bem como a alteração da composição do Conselho Nacional de Educação e do formato das consultas públicas, para garantir a aprovação da proposta indicada como versão final.

A política curricular viabilizada pelo ordenamento jurídico-estatal, expressa na BNCC, apresenta-se como política educacional induzida pelo Plano Nacional de Educação (PNE) 20142024, aprovado pela Lei N ${ }^{\circ} 13.005$, de 25 de julho de 2014 (BRASIL, 2014), ao prever, nas metas 2 e 7, respectivamente nas estratégias 2.1, 2.2 e 7.1, a regulação da oferta da Educação Básica no Brasil a partir de uma base curricular comum.

A proposição é justificada a partir do próprio ordenamento jurídico do Estado brasileiro, como pressupõem os Artigos 205 e 210 da Constituição Federal Brasileira de 1988 e os Artigos 22, 23, 26, 27, 29 e 32 da Lei de Diretrizes e Bases da Educação Nacional (LDBEN) - Lei No 9.394, de 20 de dezembro de 1996 - ao indicarem pela necessidade de currículo mínimo, currículo comum, base comum nacional (BRASIL, 1998, 1996).

A BNCC apresenta-se, portanto, como reforma curricular, integrada à política nacional de Educação Básica, capaz de promover profunda transformação na educação brasileira. Seu potencial de transformação é validado pela própria Resolução CNE/CP N 2 de 2017, ao prever, nas disposições finais e transitórias, que a BNCC terá incidência direta sobre os currículos das instituições e redes de ensino (Art. 15); sobre as matrizes de referência das avaliações e dos exames (Art. 16); sobre a política de formação de professores (Art. 17); e sobre o Programa Nacional do Livro Didático (Art. 20) (BRASIL, 2017).

Essa caracterização legal, normativa e político-pedagógica figura provocativa às pesquisas e à produção de conhecimento dos campos e dos agentes acadêmicos e científicos vinculados às

Revista de Estudios Teóricos y Epistemológicos en Política Educativa, v. 6, e2118101, p. 1-38, 2021 Disponible en: <https://www.revistas2.uepg.br/index.php/retepe> 
políticas educacionais, que tem, neste texto, uma proposta de organização dessa produção. Assim, este artigo, embora responda por um caráter mais informacional do que analítico, não deixa de expressar os fundamentos teóricos e metodológicos que o orientam como exercício ampliado de pesquisa, que se aporta à proposta da metapesquisa, com Enfoque das Epistemologias da Política Educacional (EEPE).

A metapesquisa pode ser entendida como pesquisa sobre pesquisas, ou pesquisa sobre os processos de pesquisa desenvolvidos a partir de uma temática ou campo, respondendo como organização de estratégias para a análise do objeto de pesquisa (MAINARDES, 2021). Portanto, enquanto pesquisa criteriosa e sistemática sobre as pesquisas e busca dos fundamentos teóricos e dos significados das pesquisas desenvolvidas sobre a BNCC, no Brasil, a metapesquisa orienta-se por dois movimentos principais: a) para a dimensão reflexiva, análise que busca contribuir para a compreensão da política da BNCC no Brasil; e b) para a dimensão teórico-analítica, contribuindo com o aumento da cientificidade do campo temático analisado (MAINARDES, 2018).

O Enfoque das Epistemologias da Política Educacional (EEPE), por sua vez, responde como enfoque/esquema de análise dos modos e dos processos de produção do conhecimento (TELLO, 2012; TELLO; MAINARDES, 2015). O EEPE estrutura-se a partir dos componentes analíticos da perspectiva epistemológica, cosmovisão assumida pelo pesquisador no desenvolvimento da pesquisa; do posicionamento epistemológico, como correntes teóricas do campo de estudo e posicionamento do pesquisador face ao objeto de investigação; e do enfoque epistemológico, como modo de construção metodológica da pesquisa (MAINARDES, 2021; MAINARDES; TELLO, 2016; TELLO, 2012; TELLO; MAINARDES, 2015).

Ao propor como objeto de análise a produção de conhecimento/pesquisa sobre a política curricular no Brasil, a partir da provocação materializada na definição de uma BNCC, a pesquisa assume a política curricular de forma integrada à política nacional de educação, espelhando como preocupação central a produção de conhecimento sobre as políticas educacionais. Este texto, portanto, embora objetive apresentar uma categorização possível das publicações sobre a BNCC, apresenta-se filiado ao exercício ampliado de análise crítica da produção de conhecimento no Brasil - metapesquisa - sobre a política educacional do currículo, pela perspectiva do Enfoque das Epistemologias da Política Educacional.

Contudo, atendo-se ao objetivo específico deste texto, que é a apresentação do levantamento, convém informar, de imediato, que ele foi realizado e organizado entre os meses de novembro de 2020 e fevereiro de 2021, considerando duas estratégias principais: i) levantamento das publicações em artigos científicos; ii) e levantamento das publicações decorrente de pesquisas em Programas de Pós-Graduação no Brasil - teses e dissertações. Nos dois casos, a busca deu-se a partir de dois descritores: Base Nacional Comum Curricular e BNCC.

O levantamento das publicações em artigos científicos foi realizado a partir da pesquisa em diversos sites de busca e repositórios:

a) Biblioteca Eletrônica Científica Online (SciELO Brasil);

b) Crossref Metadata Research (Crossref);

c) Scholar.google;

d) Portal de Periódicos da Coordenação de Aperfeiçoamento de Pessoal de Nível Superior (CAPES);

e) Sistema de Información Científica da Red de Revistas Científicas de América Latina y el Caribe, España y Portugal (Redalyc);

f) Directory of Open Access Journals (DOAJ).

Revista de Estudios Teóricos y Epistemológicos en Política Educativa, v. 6, e2118101, p. 1-38, 2021 Disponible en: <https://www.revistas2.uepg.br/index.php/ retepe> 
A produção de conhecimento sobre a Base Nacional Comum Curricular no Brasil: levantamento...

Após a pesquisa nas plataformas (indexadores), o levantamento foi complementado com pesquisa em revistas especializadas: e-Curriculum, Retratos da Escola, Teias, Currículo Sem Fronteiras, Espaço do Currículo, Educação \& Sociedade e Revista Brasileira de Educação (RBE). O levantamento considerou os artigos publicados em Língua Portuguesa, resultando em um levantamento total de 501 publicações.

O levantamento das publicações decorrente das pesquisas dos Programas de PósGraduação, por sua vez, foi estruturado a partir de duas plataformas: Catálogo de Teses de Dissertações da CAPES; Biblioteca Digital Brasileira de Teses e Dissertações (BDTD) e resultou na identificação de um total de 101 teses e dissertações que, somadas aos 501 artigos científicos, indicam um total de 602 publicações. Convém, ainda, destacar que as dissertações respondem tanto pelas pesquisas desenvolvidas e publicadas nas referidas bases a partir de Programas de Mestrado Profissional, quanto pelas pesquisas dos Programas de Mestrado Acadêmico. As duas modalidades de Mestrado são institucionalizadas no sistema educacional brasileiro.

\section{Uma proposta de categorização para a produção de conhecimento sobre a BNCC}

Destaca-se, de imediato, que as publicações sobre a BNCC indicadas no levantamento, quer em artigo científico ou de teses e dissertações, apresentam-se sob as marcas do já anunciado debate e das disputas político-pedagógicas, espelhando, portanto, acentuada centralidade e alcance, quer pelo expressivo volume de publicações, ou pelo conjunto das áreas com que se propõe dialogar. As Tabelas 1 e 2 apresentam a categorização dos textos incluídos no levantamento.

Tabela 1 - Categorização dos artigos sobre BNCC incluídos no levantamento (2014-2020)

\begin{tabular}{|c|c|}
\hline \multicolumn{2}{|c|}{ Artigos científicos } \\
\hline Descrição da categoria & Quantidade \\
\hline Política curricular & 200 \\
\hline Português e Literatura & 34 \\
\hline Matemática & 34 \\
\hline Fundamentos & 29 \\
\hline Ciências & 27 \\
\hline Educação Física & 27 \\
\hline Educação Infantil & 27 \\
\hline História & 22 \\
\hline Geografia & 18 \\
\hline Arte & 13 \\
\hline Ensino Religioso & 12 \\
\hline Educação Ambiental & 12 \\
\hline Alfabetização-Letramento & 11 \\
\hline Gênero e Sexualidade & 11 \\
\hline Língua Inglesa & 11 \\
\hline Sociologia & 4 \\
\hline Química & 3 \\
\hline Filosofia & 3 \\
\hline Física & 2 \\
\hline Estágio & 1 \\
\hline Total & 501 \\
\hline
\end{tabular}

Fonte: Dados da pesquisa organizados pelo autor. 
Tabela 2 - Categorização das teses e dissertações sobre BNCC incluídos no levantamento (2016-2020)

\begin{tabular}{|c|c|}
\hline \multicolumn{2}{|c|}{ Teses e dissertações } \\
\hline Descrição da categoria & Quantidade \\
\hline Política curricular & 31 \\
\hline Fundamentos & 15 \\
\hline Português e Literatura & 14 \\
\hline Educação Física & 9 \\
\hline Matemática & 8 \\
\hline História & 5 \\
\hline Alfabetização-Letramento & 2 \\
\hline Geografia & 3 \\
\hline Educação Infantil & 3 \\
\hline Ciências & 2 \\
\hline Ensino Religioso & 2 \\
\hline Língua Inglesa & 2 \\
\hline Gênero e Sexualidade & 2 \\
\hline Arte & 1 \\
\hline Educação Ambiental & 1 \\
\hline Química & 1 \\
\hline Total & 101 \\
\hline
\end{tabular}

Fonte: Dados da pesquisa organizados pelo autor.

As teses e as dissertações apresentam-se, até o momento, em menor número como consequência natural das características da produção de conhecimento a partir de pesquisas organizadas em cursos de Mestrado (acadêmico ou profissional) e Doutorado nos Programas de Pós-Graduação vinculados às universidades brasileiras. São publicações que resultam de pesquisas realizadas em períodos entre dois e quatro anos, implicando um processo mais lento de socialização dos resultados.

O olhar sobre os anos de publicação dos artigos indica 2014, ano de homologação do PNE 2014-2024, como período de início das publicações sobre a BNCC, apresentando significativa evolução nos anos subsequentes. As teses e as dissertações passam a ser publicadas no ano de 2016 (Gráficos 1 e 2).

Gráfico 1 - Quantidade de publicações de artigos por ano (2014-2020)

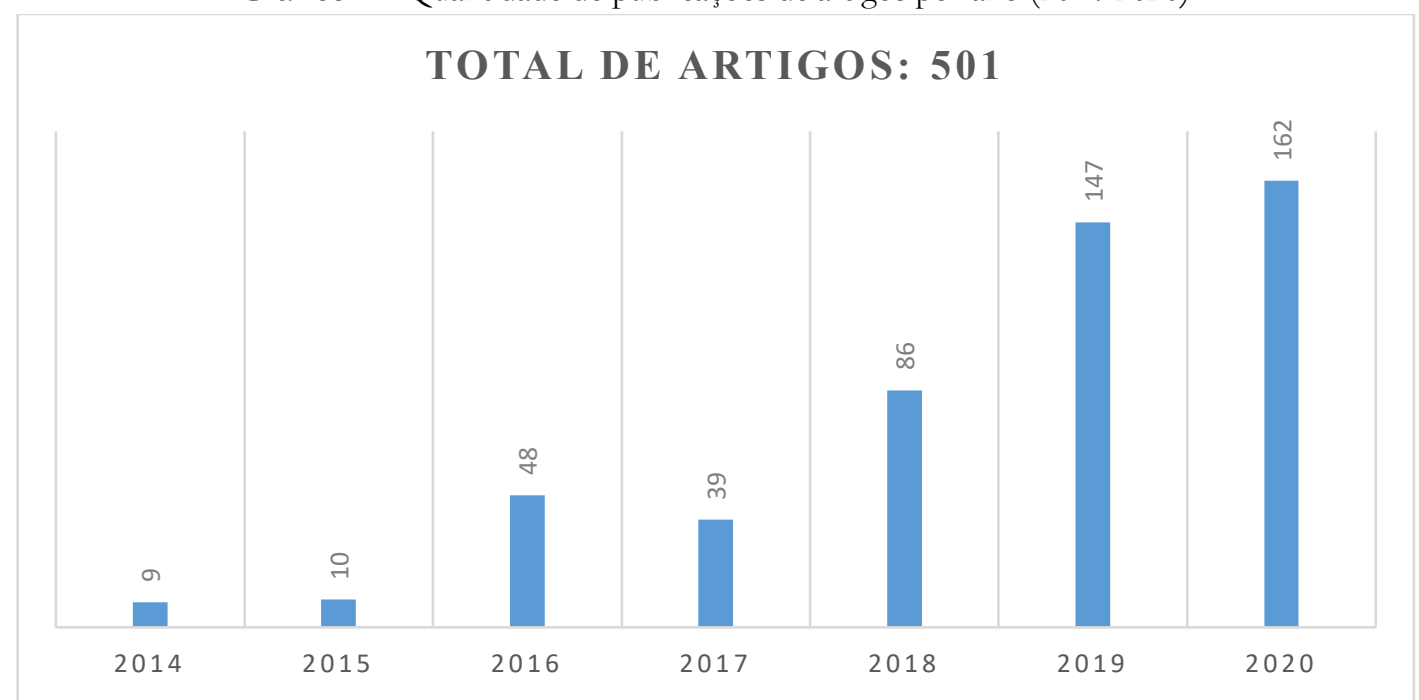

Fonte: Dados da pesquisa organizados pelo autor.

Revista de Estudios Teóricos y Epistemológicos en Política Educativa, v. 6, e2118101, p. 1-38, 2021 Disponible en: $<$ https://www.revistas2.uepg.br/index.php/retepe $>$ 
A produção de conhecimento sobre a Base Nacional Comum Curricular no Brasil: levantamento...

Gráfico 1 - Quantidade de publicações de teses e dissertações por ano (2016-2020)

\section{TOTAL DE TESES E DISSERTACÕES 101}

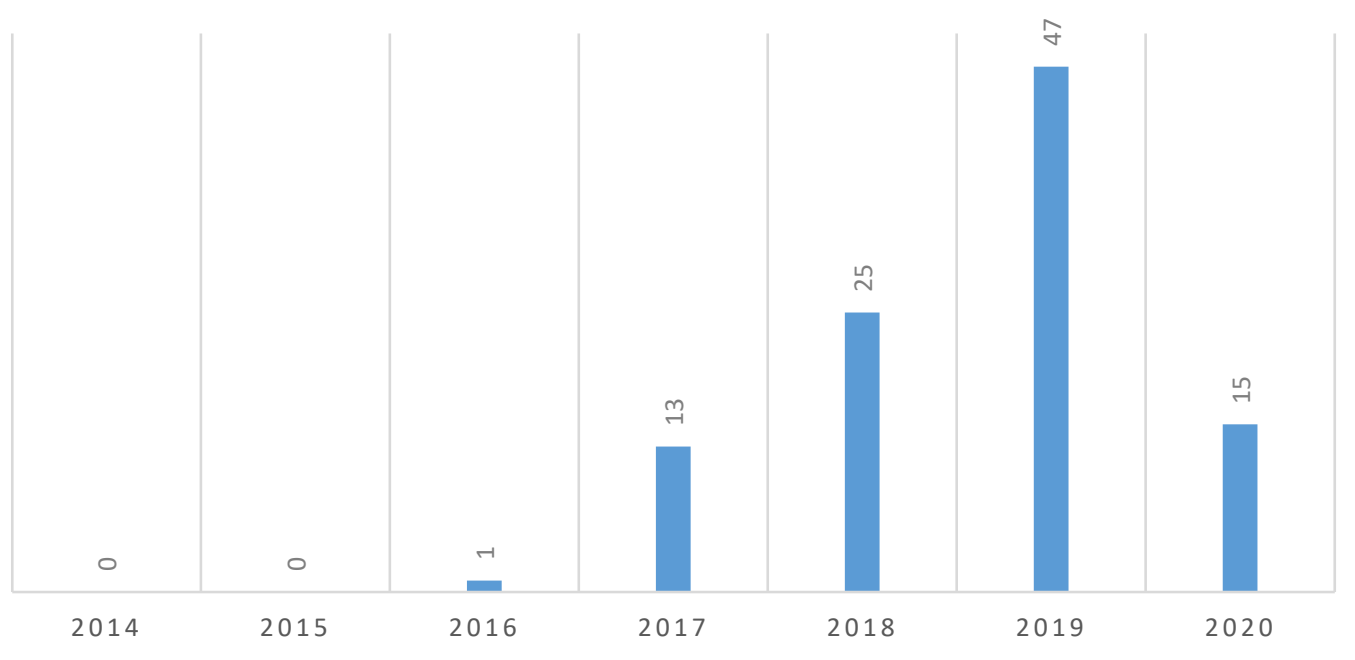

Fonte: Dados da pesquisa organizados pelo autor.

As publicações, na perspectiva da categorização, demonstram uma tendência à regularidade, com poucas variações, centradas majoritariamente na abordagem da BNCC como política curricular, seguida das produções sobre Português, Matemática e fundamentos, para na sequência abordar componentes curriculares como Ciências, Educação Física, História e Geografia, avançando para temáticas como Ensino Religioso, Educação Ambiental, Gênero e Sexualidade, e, por fim, com menor demanda de publicações os componentes como Sociologia, Química, Filosofia e Física.

A categorização e as publicações são aqui apresentadas de forma integral e completa, em um conjunto de 20 quadros, organizados de forma sequencial, a partir da categoria que apresenta maior número de publicações até a que apresenta o menor número de publicações.

Quadro 1 - Trabalhos sobre BNCC vinculados à categoria Política curricular

\section{POLÍTICA CURRICULAR - Artigos}

Total: 200

ABRAMOWICZ, Anete; CRUZ, Ana Cristina; MORUZZI, Andrea Braga. Alguns apontamentos: a quem interessa a Base Nacional Comum Curricular para a Educação Infantil? Debates em Educação, Maceió, v. 8, n. 16, p. 4665, jul./dez. 2016.

AGUIAR, Márcia Angela da Silva; DOURADO, Luiz. A BNCC na contramão do PNE 2014-2024: avaliação e perspectivas. Retratos da Escola, Brasília, v. 12, n. 23, p. 409-411, jul./out. 2018.

AGUIAR, Márcia Angela da Silva. Política Educacional e a Base Nacional Comum Curricular: o processo de formulação em questão. Currículo sem Fronteiras, [s. l.], v. 18, n. 3, p. 722-738, set./dez. 2018.

AGUIAR, Márcia Angela da Silva. Reformas conservadoras e a "Nova Educação": orientações hegemônicas no MEC e no CNE. Educação \& Sociedade, Campinas, v. 40, p. 1-24, 2019.

AGUIAR, Márcia Angela da Silva; DOURADO, Luiz Fernandes. BNCC e formação de professores: concepções, tensões, atores e estratégias. Retratos da Escola, Brasília, v. 13, n. 25, p. 33-37, jan./maio 2019.

ALBINO, Ângela Cristina Alves; ARAÚJO, Rute Pereira Alves de. Ser ou não ser um currículo? Contestações em torno da definição (anti)democrática da Base Nacional Comum Curricular. Linguagens, Educação e Sociedade, Teresina, ano 24, n. 41, p. 243-272, jan./abr. 2019.

ALBINO, Ângela Cristina Alves; SILVA, Andréia Ferreira da. BNCC e BNC da formação de professores: repensando a formação por competências. Retratos da Escola, Brasília, v. 13, n. 25, p. 137-153, jan./maio 2019.

ALMEIDA, Ivanete Bellucci Pires de; BATISTA, Sueli Soares dos Santos. Educação profissional no contexto das reformas curriculares para o ensino médio no Brasil. EccoS Revista Científica, São Paulo, n. 41, p. 17-29, set./dez. 2016.

Revista de Estudios Teóricos y Epistemológicos en Política Educativa, v. 6, e2118101, p. 1-38, 2021 Disponible en: <https://www.revistas2.uepg.br/index.php/retepe> 
ALMEIDA, Maria de Lourdes Pinto de; JUNG, Hildegard Susana. Políticas curriculares e a Base Nacional Comum Curricular: emancipação ou regulação? Educação, Santa Maria, v. 44, p. 1-14, 2018.

ALVES, Nilda. Sobre a possibilidade e a necessidade curricular de uma Base Nacional Comum. e-Curriculum, São Paulo, v. 12, n. 3, p. 1464-1479, out./dez. 2014.

ALVES, Paula Trajano de Araújo; SILVA, Solonildo Almeida da. Base Nacional Comum Curricular - BNCC: estado da arte das pesquisas produzidas nos programas de pós-graduação no Brasil nos anos de 2018 e 2019 divulgadas na Biblioteca Digital de Teses e Dissertações. Research, Society and Development, Itajaí, v. 9, n. 4, p. 1-13, 2020.

ANFLOR, Patrícia Santos; SANTAIANA, Rochele da Silva. Base Nacional Comum Curricular: estratégias de governamento dos infantis e das práticas pedagógicas docentes. Textura, Canoas, v. 22, n. 51, p. 317-338, jul./set. 2020.

ANTUNES, Marina Ferreira de Souza. O currículo como materialização do estado gerencial: a BNCC em questão. Movimento-Revista de Educação, Niterói, ano 6, n. 10, p. 43-64, jan./jun. 2019.

ARAÚJO, Edimilson Pereira de. Currículo de educação infantil: perspectivas a partir da Base Nacional Comum Curricular. Educere Et Educare, Cascavel, v. 15, n. 36, Especial Educere, p. 1-16, out. 2020.

AUGUSTINI, Rudinei Barichello. A Base Nacional Comum Curricular e a superação de conflitos em um projeto educativo. Momento: Diálogos em Educação, Rio Grande, v. 28, n. 3, p. 366-389, set./dez. 2018.

AXER, Bonnie; FRANGELLA, Rita de Cássia Prazeres; ROSÁRIO, Roberta Sales Lacê. Políticas Curriculares em uma lógica centralizadora e escapes possíveis: tecendo outras redes políticas. e-Curriculum, São Paulo, v. 15, n. 4, p. 1176-1207, out./dez. 2017.

BARBOSA, Ivone Garcia; SILVEIRA, Telma Aparecida Teles Martins; SOARES, Marcos Antônio. A BNCC da Educação Infantil e suas contradições: regulação versus autonomia. Retratos da Escola, Brasília, v. 13, n. 25, p. 77-90, jan./maio 2019.

BARBOSA, Raquel Firmino Magalhães; MARTINS, Rodrigo Lema Del Rio; MELLO, André da Silva. A educação infantil na Base Nacional Comum Curricular: avanços e retrocessos. Movimento-Revista de Educação, Niterói, ano 6, n. 10, p. 147-172, jan./jun. 2019.

BARRETO, Raquel Goulart. Entre a Base Nacional Comum Curricular e a avaliação: a substituição tecnológica no ensino fundamental. Educação \& Sociedade, Campinas, v. 37, n. 136, p. 775-791, jul./set. 2016.

BIONDO, Franco Gomes. Base Nacional Comum Curricular: contexto, significados e desalinhamentos cotidianos.

Revista Multidisciplinar de Ensino, Pesquisa, Extensão e Cultura, Rio de Janeiro, v. 8, n. 17, p. 19-33, 2019.

BISSOLI, Michelle de Freitas; MOMO, Mariangela. A implementação da Base Nacional Comum Curricular no Amazonas: desafios, conquistas e contradições em movimento. Textura, Canoas, v. 22, n. 50, p. 75-98, abr./jun. 2020.

BITTENCOURT, Jane. Educação integral no Contexto da BNCC. e-Curriculum, São Paulo, v. 17, n. 4, p. 17591780, out./dez. 2019.

BRANCO, Alessandra Batista de Godoi et al. Urgência da reforma do ensino médio e emergência da BNCC. Revista Contemporânea de Educação, Rio de Janeiro, v. 14, n. 29, p. 345-363, jan./abr. 2019.

BRANCO, Emerson Pereira et al. Uma visão crítica sobre a implantação da Base Nacional Comum Curricular em consonância com a reforma do ensino médio. Debates em Educação, Maceió, v. 10, n. 21, p. 47-70, maio/ago. 2018.

BRANDT, Andressa Graziele; LIMA, Edilene Eva de. Base Nacional Comum Curricular: disputas na produção de conhecimento. Revista da Faculdade de Educação, São Paulo, ano 15, v. 28, n. 2, p. 57-73, 2017.

BRUM, Ana Elise Rodrigues. Base Nacional Comum Curricular: cenários das pesquisas científicas sobre o processo de produção da política. RPGE - Revista on line de Política e Gestão Educacional, Araraquara, v. 24, n. 2, p. 404411, maio/ago. 2020.

BRUNS, Juliana Pedroso; NUNES, Camila da Cunha. Implicações da Base Nacional Comum Curricular sobre a avaliação no $1^{\mathrm{o}}$ ano do ensino fundamental a partir da visão dos professores. EDUCA - Revista Multidisciplinar em Educação, Porto Velho, v. 6, n. 16, p. 210-229, out./dez. 2019.

CAETANO, Maria Raquel. A Base Nacional Comum Curricular e os sujeitos que direcionam a política educacional brasileira. Revista Contrapontos, Itajaí, v. 19, n. 2, p. 132-141, jan./dez. 2019.

CAETANO, Maria Raquel. Agora o Brasil tem uma Base! a BNCC e as influências do setor empresarial. Que Base? Educação em Revista, Marília, v. 21, n. 2, p. 65-82, 2020.

CAETANO, Maria Raquel. As reformas educativas globais e a Base Nacional Comum Curricular (BNCC). Textura, Canoas, v. 22, n. 50, p. 36-53, abr./jun. 2020.

CAETANO, Maria Raquel. Os sujeitos e a proposta educacional da Base Nacional Comum Curricular: entre o público e o privado. Teoria e Prática da Educação, Maringá, v. 22, n. 3, p. 118-136, set./dez. 2019.

CAIMI, Flávia Eloisa. A história na Base Nacional Comum Curricular pluralismo de ideias ou guerra de narrativas? Revista do Lhiste, Porto Alegre, n. 4, v. 3, p. 86-92, jan./jun. 2016. 
A produção de conhecimento sobre a Base Nacional Comum Curricular no Brasil: levantamento...

CAMPOS, Gabriela Ribeiro de; GISI, Maria de Lourdes. Possíveis explicações para a semelhança entre as reformas educacionais atuais e as propostas na época da ditadura civilmilitar no Brasil. Teias, Rio de Janeiro, v. 20, n. 58, p. 345-368, jul./set. 2019.

CAMPOS, Roselane de Fátima; DURLI, Zenilde; CAMPOS, Rosânia. BNCC e privatização da educação infantil: impactos na formação de professores. Retratos da Escola, Brasília, v. 13, n. 25, p. 169-185, jan./maio 2019.

CAMPOS, Roselane Fátima; DURLI, Zenilde. BNCC para a educação infantil: é ou não é currículo? Currículo Sem Fronteiras, v. 20, n. 1, p. 251-267, jan./abr. 2020.

CÂNDIDO, Rita de Kássia; GENTILINI, João Augusto. Base Curricular Nacional: reflexões sobre autonomia escolar e o projeto político pedagógico. RBPAE - Revista Brasileira de Política e Administração da Educação, Porto Alegre, v. 33, n. 2, p. 323-336, mai./ago. 2017.

CARDONA, Márcia Pires; MELO, Débora Teixeira de. Currículo e educação infantil: os desafios para a gestão e professores. Regae - Revista de Gestão e Avaliação Educacional, Santa Maria, v. 7, n. 16, p. 111-126, set./dez. 2018.

CARVALHÊDO, Josania Lima Portela. Gestão da escola básica pública e BNCC: quais as implicações? Revista Exitus, Santarém, v. 10, p. 1-12, 2020.

CARVALHO, Janete Magalhães; LOURENÇO, Suzany Goulart. O silenciamento de professores da educação básica pela estratégia de fazê-los falar. Pro-posições, Campinas, v. 29, n. 2, p. 235-258, maio/ago. 2018.

CARVALHO, Kely Rejane Souza dos Anjos de et al. Trajetória, avanços e perspectivas da Eja face à BNCC. Educação em Revista, Marília, v. 21, n. 2, p. 51-64, 2020.

CARVALHO, Rodrigo Saballa de; SILVA, Roberto Rafael Dias da. Currículos socioemocionais, habilidades do século XXI e o investimento econômico na educação: as novas políticas curriculares em exame. Educar em Revista, Curitiba, n. 63, p. 173-190, jan./mar. 2017.

CASAGRANDE, Ana Lara, ALONSO, Katia Morosov; SILVA, Danilo Garcia da. Base Nacional Comum Curricular e ensino médio: reflexões à luz da conjuntura contemporânea. Revista Diálogo Educacional, Curitiba, v. 19 , n. 60 , p. 407-425, jan./mar. 2019.

CÁSSIO, Fernando. Base Nacional Comum Curricular: ponto de saturação e retrocesso na educação. Retratos da Escola, Brasília, v. 12, n. 23, p. 239-253, jul./out. 2018.

CASTRO, Luzia de Marilac Pereira; PEREIRA, Sandra Márcia Campos. Base Nacional Comum Curricular: é currículo prescrito ou documento norteador? Espaço do Currículo (online), João Pessoa, v. 12, n. 3, p. 431-433, set./dez. 2019.

CASTRO, Maria Helena Guimarães de. Breve histórico do processo de elaboração da Base Nacional Comum Curricular no Brasil. Em Aberto, Brasília, v. 33, n. 107, p. 95-112, jan./abr. 2020.

CERICATO, Itale; CERICATO, Lauri. A Formação de Professores e as novas Competências Gerais Propostas pela BNCC. Revista Veras, São Paulo, v. 8, n. 2, p. 137-149, jul./dez. 2018.

CHIZZOTTI, Antônio; SILVA, Rosa Eulalia Vital da. Base Nacional Comum Curricular e as classes multisseriadas na Amazônia. e-Curriculum, São Paulo, v. 16, n. 4, p. 1408-1436, out./dez. 2018.

CORRÊA, Adriana; MORGADO, José Carlos. O emaranhado de fios que envolve os contextos de influência e de produção da BNCC. Teias, Rio de Janeiro, v. 20, n. 59, p. 235-250, out./dez. 2019.

CORRÊA, Cintia Chung Marques. A implementação de um novo currículo nas escolas da rede municipal de Petrópolis-reflexões preliminares para a Base Nacional Comum Curricular. EccoS Revista Científica, São Paulo, n. 43, p. 117-134, maio/ago. 2017.

CORREIA, Divanez Alves et al. A educação profissional tecnológica na Base Nacional Comum Curricular: concepções e contradições. Revista Prática Docente, Confresa, v. 5, n. 1, p. 563-581, jan./abr. 2020.

CORTI, Ana Paula. Política e significantes vazios: uma análise da reforma do ensino médio de 2017. Educação em Revista, Belo Horizonte, v. 35, p. 1-20, jan./dez. 2019.

CÓSSIO, Maria de Fátima. Base Comum Nacional: uma discussão para além do currículo. e-Curriculum, São Paulo, v. 12, n. 3, p. 1570-1590, out./dez. 2014.

COSTA, Cristiana Marinho da. Diálogo acerca das competências socioemocionais e suas interfaces com a BNCC e a formação docente. Revista Internacional Educon, Aracaju, v. I, n.1, p. 1-13, set./dez. 2020.

COSTA, Hugo Heleno Camilo. "Seríamos a Política que Criticamos?”: a interlocução do povo da Geografia na produção da BNCC. Revista Brasileira de Educação em Geografia, Campinas, v. 10, n. 19, p. 125-152, jan./jun. 2020.

COSTA, Hugo Heleno Camilo; LOPES, Alice Casimiro. A contextualização do conhecimento no ensino médio: tentativas de controle do outro. Educação \& Sociedade, Campinas, v. 39, n. 143, p. 301-320, abr./jun. 2018.

COSTA, Maria da Conceição dos Santos; FARIAS, Maria Celeste Gomes de; SOUZA, Michele Borges de. A Base Nacional Comum Curricular (BNCC) e a formação de professores no Brasil: retrocessos, precarização do trabalho e desintelectualização docente. Movimento-Revista de Educação, Niterói, ano 6, n. 10, p. 91-120, jan./jun. 2019.

Revista de Estudios Teóricos y Epistemológicos en Política Educativa, v. 6, e2118101, p. 1-38, 2021 Disponible en: <https://www.revistas2.uepg.br/index.php/retepe> 
COSTA, Marilda de Oliveira; SILVA, Leonardo Almeida da. Educação e Democracia: Base Nacional Comum Curricular e novo ensino médio sob a ótica de entidades acadêmicas da área educacional. Revista Brasileira de Educação, Rio de Janeiro, v. 24, p. 1-23, 2019.

COSTA, Raquel da; MOLINA, Adão Aparecido. Elaboração e implementação da BNCC (2015/2017) na Educação Pública Brasileira: aproximações com o ideário político-ideológico da UNESCO. Revista Cocar, v. 14, n. 29, p. 477-497, maio/ago. 2020

COSTA, Rejane Peres Neto; NASCIMENTO, Anelise Monteiro do, NEVES, Luana Ramos. Base Nacional Comum Curricular: implementação da proposta curricular para a educação infantil no município de Nova Iguaçu. Colloquium Humanarum, Presidente Prudente, v. 16, n. 4, p. 35-49, out./dez. 2019.

COSTOLA, Andresa; BORGHI, Raquel Fontes. Os reformadores empresariais e as políticas educacionais: análise do Movimento Todos pela Base Nacional Comum. RPGE- Revista online de Política e Gestão Educacional, Araraquara, v. 22, n. esp. 3, p. 1313-1324, dez. 2018.

CUNHA, Érika Virgílio Rodrigues da; LOPES, Alice Casimiro. Base Nacional Comum Curricular no Brasil: regularidade na dispersão. Investigación Cualitativa, v. 2, n. 2, p. 23-35, 2017.

CUNHA, Kátia Silva; SILVA, Janini de Paula da. Sobre base e bases curriculares, nacionais, comuns: de que currículo estamos falando? e-Curriculum, São Paulo, v. 14, n. 4, p. 1236-1257, out./dez. 2016.

DAL'IGNA, Maria Cláudia; SCHERER, Renata Porcher; SILVA, Miriã Zimmermann da. Trabalho docente, gênero e políticas neoliberais e neoconservadoras: uma leitura crítica da Base Nacional Comum de formação de professores da Educação Básica. Práxis Educativa, Ponta Grossa, v. 15, p. 1-21, 2020.

DIAS, Marcelo de Oliveira. A Sociedade Brasileira de Educação Matemática e o processo de construção da Base Nacional Comum Curricular. Praxis \& Saber, Tunja, v. 11, n. 26, p. 1-17, 2020.

DOURADO, Luiz Fernandes; SIQUEIRA, Romilson Martins. A arte do disfarce: BNCC como gestão e regulação do currículo. RBPAE - Revista Brasileira de Política e Administração da Educação, Porto Alegre, v. 35, n. 2, p. 291-306, maio/ago. 2019.

DUARTE, Adriana Maria Cancella et al. A contrarreforma do ensino médio e as perdas de direitos sociais no Brasil. Roteiro, Joaçaba, v. 45, p. 1-26, jan./dez. 2020.

ESQUINSANI, Rosimar Serena Siqueira; CRUZ SOBRINHO, Sidinei. O retrocesso da reforma do ensino médio, a BNCC, o neoliberalismo educacional e a marginalização dos institutos federais - IFs. Inter-Ação, Goiânia, v. 45, n. 1, p. 151-168, 2020.

FAGUNDES, Heldina Pereira Pinto; CARDOSO, Berta Leni Costa. quinze anos da implementação da Lei 10.639/2003: desafios e tensões no contexto da Base Nacional Comum Curricular. Revista Exitus, Santarém, v. 9, n. 3, p. 59-86, jul./set. 2019.

FARIAS, Cristiane dos Santos; MAGALHÃES, Cassiana. Documentos oficiais de política educacional brasileira e portuguesa: aproximações BNCC E OCEPE. Educação em Revista, Marília, v. 21, n. 2, p. 83-104, 2020.

FARIAS, Isabel Maria Sabino de. O discurso curricular da proposta para BNC da formação de professores da Educação Básica. Retratos da Escola, Brasília, v. 13, n. 25, p. 155-168, jan./maio 2019.

FERNANDES, Claudia de Oliveira. Avaliação, currículo e suas implicações - projetos de sociedade em disputa. Retratos da Escola, Brasília, v. 9, n. 17, p. 397-408, jul./dez. 2015.

FERRAÇO, Carlos Eduardo. Práticas-políticas curriculares cotidianas como possibilidades de resistência aos clichês e à Base Nacional Comum Curricular (BNCC). Linhas Críticas, Brasília, v. 23, n. 52, p. 524-537, jun./set. 2017.

FERRAÇO, Carlos Eduardo; SUSSEKIND, Maria Luiza; GOMES, Marco Antonio Oliva. Sobre políticas em currículo e resistências e invenções e cotidianos escolares e desafios e.... "vai ter luta!" Espaço do Currículo (online), João Pessoa, v. 10, n. 3, p. 356-365, set./dez. 2017.

FERREIRA, Fabíola da Silva; SANTOS, Fabiano Antonio dos. As Estratégias do "Movimento pela Base" na construção da BNCC: consenso e privatização. Doxa: Revista Brasileira de Psicologia e Educação, Araraquara, v. 22, n. 1, p. 189-208, jan./jun. 2020.

FERREIRA, Fernando Wirthmann; ABREU, Richard James Lopes de; LOUZADA-SILVA, Daniel. Desafios da articulação entre o novo Ensino Médio e a BNCC: o caso do Distrito Federal. Em Aberto, Brasília, v. 33, n. 107, p. 215-222, jan./abr. 2020.

FERRETI, Celso João; SILVA, Monica Ribeiro da. Reforma do ensino médio no contexto da medida provisória n. 746/2016: Estado, currículo e disputas por hegemonia. Educação \& Sociedade, Campinas, v. 38, n. 139, p. 385404, abr./jun. 2017.

FIGUEIREDO, Arthane Menezes; OLIVEIRA, Maria Celes Monteiro Ferreira; SILVA, Selma Gomes da. A política de formação continuada para professores de sociologia em tempos atuais: desafios frente à contrarreforma do ensino médio. Revista Cocar, Belém, v. 13, n. 27, p. 157-178, set./dez. 2019.

FILHA, Tatiana M. S. P.; COSTA, Daianny Madalena da. A BNCC e sua provação para a autonomia da escola e para a (re)significação do currículo. Textura, Canoas, v. 22, n. 50, p. 221-240, abr./jun. 2020.

FRANCINI, Eduardo Fernando; MORENO-PIZANI, Alejandra. Os impactos da Base Nacional Comum Curricular na construção do currículo piracicabano. e-Curriculum, São Paulo, v. 18, n. 4, p. 1645-1667, 2020. 
A produção de conhecimento sobre a Base Nacional Comum Curricular no Brasil: levantamento...

FRANGELLA, Rita de Cássia Prazeres. Um pacto curricular: o pacto nacional pela alfabetização na idade certa e o desenho de uma Base Comum Nacional. Educação em Revista, Belo Horizonte, v. 32, n. 2, p. 69-89, jun./set. 2016.

FRANGELLA, Rita de Cássia Prazeres; DIAS, Rosanne Evangelista. Os sentidos de docência na BNCC: efeitos para o currículo da educação básica e da formação/atuação de professores. Educação Unisinos, São Leopoldo, v. 22, n. 1, p. 7-15, jan./mar. 2018.

FREITAS, Adriano Vargas; RIBEIRO, William de Goes. Disputas pela Base Nacional Comum Curricular: pensando em diferença e em educação. Teias, Rio de Janeiro, v. 19, n. 54, p. 333-347, jul./set. 2018.

FREITAS, Fabrício Monte; SILVA, João Alberto da; LEITE, Maria Cecília Lorea. Diretrizes invisíveis e regras distributivas nas políticas curriculares da nova BNCC. Currículo sem Fronteiras, v. 18, n. 3, p. 857-870, set./dez. 2018.

FREITAS, Helena Costa Lopes de. 30 Anos da Constituição avanços e retrocessos na formação de professores. Retratos da Escola, Brasília, v. 12, n. 24, p. 511-527, nov./dez. 2018.

FREITAS, Luiz Carlos de. Os reformadores empresariais da educação e a disputa pelo controle do processo pedagógico na escola. Educação \& Sociedade, Campinas, v. 35, n. 129, p. 1085-1114, out./dez. 2014.

GIROTTO, Eduardo Donizeti. Entre o abstracionismo pedagógico e os territórios de luta: a Base Nacional Comum Curricular e a defesa da escola pública. Horizontes, Itatiba, v. 36, n. 1, p. 16-30, jan./abr. 2018.

GIROTTO, Eduardo Donizeti. Pode a política pública mentir? a Base Nacional Comum Curricular e a disputa da qualidade educacional. Educação \& Sociedade, Campinas, v. 40, p. 1-21, 2019.

GOBBI, Marcia Aparecida. Entreatos: precisamos de BNCC ou seria melhor contar com a Base? a Base Nacional Comum Curricular de Educação Infantil. Debates em Educação, Maceió, v. 8, n. 16, p. 118-135, jul./dez. 2016.

GONÇALVES, Amanda Melchiotti; GUERRA, Dhyovana. Competências gerais da Base Nacional Comum Curricular e parâmetros curriculares nacionais: continuidade e conservação. Revista Teoria e Prática da Educação, Maringá, v. 21, n. 3, p. 27-39, set./dez. 2018.

GONÇALVES, Amanda Melchiotti; GUERRA, Dhyovana; DEITOS, Roberto Antonio. Avaliação em larga escala e a Base Nacional Comum Curricular (BNCC): dimensões da política de contenção e liberação no Brasil. RPGE revista online de política e gestão educacional, Araraquara, v. 24, n. esp. 1, p. 891-908, ago. 2020.

GONÇALVES, Rafael Marques; MACHADO, Tânia Mara Rezende; CORREIA, Maria José Nascimento. A BNCC na contramão das demandas sociais: planejamento com e planejamento para. Revista Práxis Educacional, Vitória da Conquista, v. 16, n. 38, p. 338-351, jan./mar. 2020.

GONÇALVES, Rafael Marques; QUINTANNA, Adriana Ribeiro dos Santos. A BNCC e os professores: uma discussão sobre autoria e autonomia de professores. Pesquisa e Ensino, Barreiras, v. 1, p. 1-18, 2020.

GUIMARÃES, Lucas Peres; CASTRO, Denise Leal de. Visão dos professores de ciências da rede municipal de Barra Mansa, diante dos desafios da Base Nacional Comum Curricular (BNCC). Horizontes - Revista de Educação, Dourados, v. 8, n. 15, p. 6-19, jan./jun. 2020.

HYPOLITO, Álvaro Moreira. BNCC, Agenda global e formação docente. Retratos da Escola, Brasília, v. 13, n. 25, p. 187-201, jan./maio 2019.

HYPOLITO, Álvaro Moreira; JORGE, Tiago. OCDE, PISA e avaliação em larga escala no Brasil: algumas implicações. Sisyphus Journal of Education, Lisboa, v. 8, p. 10-27, 2020.

JORGE, Juliana Macedo Balthazar; SOUZA, Vânia de Fátima Matias de. A ciranda das políticas educacionais para a infância: a roda-viva histórica que permeia a Base Nacional Comum curricular. Aurora, Marília, v. 12, n. 2, p. 6176, jul./dez. 2019.

JURACH, Ivanise; POSSANI, Taíse Neves. Análise discursiva da BNCC: construção ou (des)construção da educação escolar pública brasileira? Fólio - Revista de Letras Vitória da Conquista, v. 11, n. 1, p. 533-558, jan./jun. 2019.

KLEIN, Delci Heinli; FROHLICH, Marcelo Augusto; KONRATH, Raquel Dilly. Base Nacional Comum Curricular - BNCC: documento em análise. Revista Acadêmica Licencia\&acturas, Ivoti, v. 4, n. 1, p. 65-70, 2016.

KOEPSEL, Eliana Clúdia Navarro; GARCIA, Sandra Regina de Oliveira; CZERNISZ, Eliane Cleide da Silva. A tríade da reforma do ensino médio brasileiro: Lei n. 13.415/2017, BNCC e DCNEM. Educação em Revista, Belo Horizonte, v. 36, p. 1-14, 2020.

LIMA, Iana Gomes de; HYPOLITO, Álvaro Moreira. A expansão do neoconservadorismo na educação brasileira. Educação e Pesquisa, São Paulo, v. 45, p. 1-13, 2019.

LIPSUCH, Graciele; LIMA, Michelle Fernandes. Políticas nacionais de avaliação para a alfabetização: o que muda com a Base Nacional Comum Curricular (BNCC)? Olhar de professor, Ponta Grossa, v. 23, p. 1-15, 2020.

LOPES, Alice Casimiro. Itinerários formativos na BNCC do ensino médio: identificações docentes e projetos de vida juvenis. Retratos da Escola, Brasília, v. 13, n. 25, p. 59-75, jan./maio 2019.

MACEDO, Elizabeth. As demandas conservadoras do movimento Escola sem Partido e a Base Nacional Curricular Comum. Educação \& Sociedade, Campinas, v. 38, n. 139, p. 507-524, abr./jun. 2017. 
MACEDO, Elizabeth. Base Nacional Comum para Currículos: direitos de aprendizagem e desenvolvimento para quem? Educação \& Sociedade, Campinas, v. 36, n. 133, p. 891-908, out./dez. 2015.

MACEDO, Elizabeth. Base Nacional Curricular Comum: a falsa oposição entre conhecimento para fazer algo e conhecimento em si. Educação em Revista, Belo Horizonte, v. 32, n. 2, p. 45-67, abr./jun. 2016.

MACEDO, Elizabeth. Base Nacional Curricular Comum: novas formas de sociabilidade produzindo sentidos para educação. e-Curriculum, São Paulo, v, 12, n. 3, p. 1530-1555, 2014.

MACEDO, Elizabeth; FRANGELLA, Rita de Cássia. Apresentação - Políticas de Currículo ou Base Nacional Comum: debates e tensões. Educação em Revista, Belo Horizonte, v. 32, n. 2, p. 13-17, jun./set. 2016.

MACEDO, Elizabeth Fernandes de. Fazendo a base virar realidade: competências e o germe da comparação. Retratos da Escola, Brasília, v. 13, n. 25, p. 39-58, jan./maio 2019.

MACHADO, Roseli Belmonte; LOCKMANN, Kamila. Base Nacional Comum, escola, professor. e-Curriculum, São Paulo, v. 12, n. 3, p. 1591-1613, out./dez. 2014.

MACIELI, Cilene Maria Lima Antunes et al. Visão de professores de escolas de Cuiabá/MT e Campo Verde/MT sobre a Base Nacional Comum Curricular (BNCC). Revista Educação Pública, Cuiabá, v. 26, n. 62/2, p. 657 673, maio/ago. 2017.

MAGALHÃES, Solange Martins Oliveira. Formação Continuada de Professores: uma análise epistemológica das concepções postas no Plano Nacional da Educação (PNE 2014-2024) e na Base Nacional Comum Curricular (BNCC 2015). Revista Linhas, Florianópolis, v. 20, n. 43, p. 184-204, maio/ago. 2019.

MAQUINÉ, Gilmara Oliveira; AZEVEDO, Rosa Oliveira Marins. Competências na formação de professores: da LDB à BNCC. REVES - Revista Relações Sociais, Viçosa, v. 1, n. 1, p. 111-120, 2018.

MARCHAND, Patrícia; BAIRROS, Mariângela; AMARAL, Julia. A Base Nacional Comum Curricular do ensino médio, as definições do Banco Mundial e os desafios da educação pública no Brasil. Políticas Educativas, Santa Maria, v. 11, n. 2, p. 69-88, 2018.

MARCHELLI, Paulo Sergio. Base Nacional Comum Curricular e formação de professores: o foco na organização interdisciplinar do ensino e aprendizagem. Revista de Estudos de Cultural, Aracaju, n. 7, p. 54-70, jan./abr. 2017. MARCHELLI, Paulo Sergio. Da LDB 4.024/61 ao debate contemporâneo sobre as Base Curriculares Nacionais. e-Curriculum, São Paulo, v. 12, n. 3, p. 1480-1511, out./dez. 2014.

MARIANI, Vanessa de Cassia Pistóia; SEPEL, Lenira Maria Nunes. Entendimentos e participação docente no processo de elaboração e tramitação da BNCC. Research, Society and Development, Itajaí, v. 8, n. $12,2019$.

MARIANI, Vanessa de Cassia Pistóia; SEPEL, Lenira Maria Nunes. Planejamentos docentes: uma análise sob a perspectiva das unidades temáticas da BNCC. Research, Society and Development, Itajaí, v. 8, n. $12,2019$.

MARQUES, Circe Mara; PEGORARO, Ludimar; SILVA, Ezequiel Theodoro da. Do assistencialismo à Base Nacional Comum Curricular (BNCC): movimentos legais e políticos na Educação Infantil. Revista Linhas, Florianópolis, v. 20, n. 42, p. 255-280, jan./abr. 2019.

MARSIGLIA, Ana Carolina Galvão et al. A Base Nacional Comum Curricular: um novo episódio de esvaziamento da escola no Brasil. Germinal: Marxismo e Educação em Debate, Salvador, v. 9, n. 1, p. 107-121, abr. 2017.

MARTINS JUNIOR, Luiz; DIAS, Julice; VOOS, Jordelina Beatriz Anacleto. Entrecruzando a Base Comum Curricular e a formação de professores da Educação Infantil. Textura, Canoas, v. 22, n. 50, p. 182-201, abr./jun. 2020.

MARTINS, Rosana Maria; CARVALHO, Andreia Cristina Santiago; FARIAS, Marly Souza Brito. A (re)estruturação da Diretriz Curricular Municipal de Rondonópolis/MT: contribuições do estudo colaborativo do OBEDUC/MT. Revista Devir Educação, Lavras, v. 3, n. 2, p. 75-91, jul./dez. 2019.

MENEZES, Luís Carlos de. Ensino Médio - etapa conclusiva de uma educação em crise. Estudos Avançados, São Paulo, v. 32, n. 94, p. 111-118, 2018.

MERITH-CLARAS, Sônia. O fazer verdadeiro e a transição de governo na construção da Base Nacional Comum Curricular: um documento também político. Estudos Semióticos, São Paulo, v. 15, n. 1, p. 98-118, ago. 2019.

MERLI, Angélica de Almeida. A homologação da Base Nacional Comum Curricular (BNCC) e suas implicações para a construção de propostas curriculares. Movimento-Revista de Educação, Niterói, ano 6, n. 10, p. 173-194, jan./jun. 2019.

MICARELLO, Hilda Aparecida Linhares da Silva. A BNCC no contexto de ameaças ao estado democrático de direito. EccoS Revista Científica, São Paulo, n. 41, p. 61-75, set./dez. 2016.

MICHETTI, Miqueli. Entre a legitimação e a crítica: As disputas acerca da Base Nacional Comum Curricular. Revista Brasileira de Ciências Sociais, São Paulo, v. 35, n. 102, p. 1-19, 2020.

MUELLER, Rafael Rodrigo; CECHINEL, André. A privatização da educação brasileira e a BNCC do ensino médio: parceria para as competências socioemocionais. Educação, Santa Maria, v. 45, p. 1-22, 2020.

NEIRA, Marcos Garcia; ALVIANO JÚNIOR, Wilson; ALMEIDA, Déberson Ferreira de. A primeira e segunda versões da BNCC: construção, intenções e condicionantes. EccoS Revista Científica, São Paulo, n. 41, p. 31-44, set./dez. 2016. 
A produção de conhecimento sobre a Base Nacional Comum Curricular no Brasil: levantamento...

NOGUEIRA, Luciana; DIAS, Juciele Pereira. Base Nacional Comum Curricular (BNCC): sentidos em disputa na lógica das competências. Revista Investigações, Recife, v. 31, n. 2, p. 26-48, dez. 2018

NOVAIS, Gercina Santana; NUNES, Silma do Carmo. A Base Nacional Comum Curricular: uma estratégia a favor da educação emancipatória das infâncias e redução das desigualdades educacionais? Ensino Em Re-Vista, Uberlândia, v. 25, n. especial, p. 1056-1086, 2018.

OLIVEIRA, Ana Gardennya Linard Sírio. A implementação do documento curricular referencial do Ceará (BNCC) em regime de colaboração. Brazilian Journal of Development, São José dos Pinhais, v. 6, n. 4, p. 19776-19784, abr. 2020.

OLIVEIRA, Marcia Lisbôa Costa de; ELETÉRIO, Lúcia Helena Abreu. Pensando as Margens: currículo e saberes locais na Base Nacional Comum Curricular. Pensares em Revista, São Gonçalo, n. 14, p. 170-191, 2019.

OLIVEIRA, Zilma de Moraes Ramos de. A Construção da Base Nacional Comum Curricular para a Educação Infantil. Revista Entreideias, Salvador, v. 8, n. 2, p. 75-94, maio/ago. 2019.

ORNELLAS, Janaína Farias de; SILVA, Luana Cristeinsen. O ensino fundamental da BNCC: proposta de um currículo na contramão do conhecimento. Espaço do Currículo (online), João Pessoa, v. 12, n. 2, p. 309-325, maio/ago. 2019.

ORRÚ, Sílvia Ester. Base Nacional Comum Curricular: à contramão dos espaços de aprendizagem inovadores e inclusivos. Revista Tempos e Espaços em Educação, São Cristóvão, v. 11, n. 25, p. 141-154, abr./jun. 2018.

PANDINI-SIMIANO, Luciane; BUSS-SIMÃO, Márcia. Base Nacional Comum Curricular para a educação infantil: entre desafios e possibilidades dos campos de experiência educativa. EccoS Revista Científica, São Paulo, n. 41, p. 77-90, set./dez. 2016.

PEREIRA, Crígina Cibelle; PINHEIRO, Joelma Uchoa; FEITOSA, Francisco Antonio Rocha. A BNCC no descompasso entre o ideal do currículo formal e interposições do currículo real. Debates em Educação, Maceió, v. 11, n. 25, p. 344-364, set./dez. 2019.

PEREIRA, Fábio de Barros; OLIVEIRA, Inês Barbosa de. Ponderações ao currículo mínimo da rede estadual do Rio de Janeiro: uma contribuição ao debate em torno da Base Comum Nacional. e-Curriculum, São Paulo, v. 12, n. 3, p. 1669-1692, out./dez. 2014.

PEREIRA, Jennifer Nascimento; EVANGELISTA, Olinda. Quando o capital educa o educador: BNCC, Nova Escola e Lemann. Movimento-Revista de Educação, Niterói, ano 6, n. 10, p. 65-90, jan./jun. 2019.

PERONI, Vera Maria Vidal; CAETANO, Maria Raquel. O público e o privado na educação: projetos em disputa? Retratos da Escola, Brasília, v. 9, n. 17, p. 337-352, jul./dez. 2015.

PERONI, Vera; CAETANO, Maria Raquel; LIMA, Paula de. Reformas educacionais de hoje: as implicações para a democracia. Retratos da Escola, Brasília, v. 11, n. 21, p. 415-432, jul./dez. 2017.

PFEIFFER, Claudia; GRIGOLETTO, Marisa. Reforma do ensino médio e BNCC - divisões, disputas e interdições de sentidos. Revista Investigações, Recife, v. 31, n. 2, p. 7-25, dez. 2018.

PICOLI, Bruno Antonio. Base Nacional Comum Curricular e o canto da sereia da educação normalizante: a articulação neoliberal-neoconservadora e o dever eticoestético da resistência. Revista de Estudios Teóricos y Epistemológicos en Política Educativa, Ponta Grossa, v. 5, p. 1-23, 2020.

PIZOLATI, Audrei Rodrigo da Conceição. A influição do discurso neoliberal na governamentalidade pedagógica no Brasil contemporâneo. Revista Cocar, Belém, v. 14, n. 28, p. 521-540, jan./abr. 2020.

PONCE, Branca Jurema; ARAÚJO, Wesley. A justiça curricular em tempos de implementação da BNCC e de desprezo pelo PNE (2014-2024). e-Curriculum, São Paulo, v. 17, n. 3, p. 1045-1074, jul./set. 2019.

PONCIANO, Jéssica Kurak et al. A "Base Nacional Comum Curricular” e a Lei no 13.415/2017: educação dos jovens brasileiros de volta aos "anos de chumbo". Educação, Santa Maria, v. 44, p. 1-22, 2019.

PUREZA, Mirian Saraiva; SCHMIDT, Elisabeth Brandão. A formação continuada de professores e a educação inclusiva sob o prisma do ensino de nove anos e da Base Nacional Comum Curricular. RELACult - Revista LatinoAmericana de Estudos em Cultura e Sociedade, Foz do Iguaçu, v. 5, n. 1131, ed. especial, p. 1-8, abr. 2019.

RAMOS, Jéssica Rochelly da Silva; CUNHA, Kátia Silva. A educação do campo como Política Curricular nas "Amazônias": territórios, insurgências e re(existências). Teias, Rio de Janeiro, v. 21, n. 61, p. 183-200, abr./jun. 2020.

RIBEIRO, William de Goes; CRAVEIRO, Clarissa Bastos. Precisamos de uma Base Nacional Comum Curricular? Linhas Críticas, Brasília, v. 23, n. 50, p. 51-69, fev./maio 2017.

ROCHA, Nathália Fernandes Egito; PEREIRA, Maria Zuleide da Costa. A prosopopeia da Base Nacional Comum Curricular e a participação docente. Horizontes, Itatiba, v. 36, n. 1, p. 49-63, jan./abr. 2018.

ROCHA, Nathália Fernandes Egito; PEREIRA, Maria Zuleide da Costa. Base Nacional Comum Curricular: os discursos sobre a docência. Retratos da Escola, Brasília, v. 13, n. 25, p. 203-217, jan./maio 2019.

ROCHA, Nathália Fernandes Egito; PEREIRA, Maria Zuleide da Costa. O que dizem sobre a BNCC. Produções sobre a Base Nacional Comum Curricular (BNCC) no período de 2010 a 2015. Espaço do Currículo (online), João Pessoa, v. 9, n. 2, p. 215-236, maio/ago. 2016. 
RODRIGUES, Larissa Zancan; PEREIRA, Beatriz; MOHR, Adriana. O documento "Proposta para Base Nacional Comum da Formação de Professores da Educação Básica” (BNCFP): Dez razões para temer e contestar a BNCFP. RBPEC, Belo Horizonte, n. 20, p. 1-39, 2020.

ROSA, Luciane Oliveira da; FERREIRA, Valéria Silva. A rede do movimento pela Base e sua influência na Base Nacional Comum Curricular brasileira. Revista Teoria e Prática da Educação, Maringá, v. 21, n. 2, p. 115-130, maio/ago. 2018.

SABÓIA, Valquíria Soares Mota; BARBOSA, Rozilda Pereira. Base Nacional Comum Curricular: competências, habilidades e o planejamento escolar. Revista Pemo, Fortaleza, v. 2, n. 1, p. 1-13, 2020.

SANTOS, André Vitor Fernandes dos; FERREIRA, Marcia Serra. BNCC: múltiplas posições e olhares para pensar a qualidade da educação e a autonomia docente. Em Aberto, Brasília, v. 33, n. 107, p. 19-23, jan./abr. 2020

SANTOS, André Vitor Fernandes dos; FERREIRA, Marcia Serra. Currículo Nacional Comum: uma questão de qualidade? Em Aberto, Brasília, v. 33, n. 107, p. 27-44, jan./abr. 2020.

SANTOS, Geniana dos; DESTRO, Denise de Souza. Qual é o lugar da formação humana nas políticas curriculares contemporâneas? Currículo sem Fronteiras, v. 19, n. 3, p. 893-909, set./dez. 2019.

SANTOS, José Erimar dos. Desordem e regresso: a "nova" reforma do ensino médio e a deficiência cívica sem o saber pensar o espaço e sem o saber nele agir. Geografia Ensino \& Pesquisa, Santa Maria, v. 23, p. 1-48, 2019.

SANTOS, Luciola Licinio. Administrando o currículo ou os efeitos da gestão no desenvolvimento curricular. Educação em Revista, Belo Horizonte, n. 33, p. 1-22, 2017.

SAUL, Alexandre; GARCIA, Alexandra. Políticas e práticas curriculares nas escolas: resistindo e (re)existindo ao poder hegemônico. e-Curriculum, São Paulo, v. 14, n. 4, p. 1184-1192, out./dez. 2016.

SAVIANI, Dermeval. Educação Escolar, Currículo e Sociedade: o problema da Base Nacional Comum Curricular. Movimento Revista de Educação, Rio de Janeiro, ano 3, n. 4, p. 54-84, 2016.

SILVA, Edileuza Fernandes; PAULA, Alessandra Valéria de. BNCC do ensino médio e trabalho pedagógico da escola: propostas da audiência pública de Brasília. Currículo sem Fronteiras, v. 19, n. 3, p. 992-1010, set./dez. 2019.

SILVA, Francisco Canindé. Na Base, como os professores veem a Base? sobre currículos e BNCC. Textura, Canoas, v. 22, n. 50, p. 99-117, abr./jun. 2020.

SILVA, Francisco Thiago. O nacional e o comum no ensino médio: autonomia docente na organização do trabalho pedagógico. Em Aberto, Brasília, v. 33, n. 107, p. 155-172, jan./abr. 2020.

SILVA, Ileizi Luciana Fiorelli; ALVES NETO, Henrique Fernandes; VICENTE, Daniel Vitor. A proposta da Base Nacional Comum Curricular e o debate entre 1988 e 2015. Ciências Sociais Unisinos, São Leopoldo, v. 51, n. 3, p. 330-342, set./ dez. 2015.

SILVA, Leda Regina Bitencourt da; ARAÚJO, Gilvan Charles Cerqueira de. Currículo, BNCC e Base Nacional Comum de formação de professores. Revista de Educação, Brasília, ano 42, n. 160, p. 46-64, out./dez. 2019.

SILVA, Monica Ribeiro da. A BNCC da Reforma do Ensino Médio: o resgate de um empoeirado discurso. Educação em Revista, Belo Horizonte, v. 34, p. 1-15, 2018

SILVA, Monica Ribeiro da. Currículo, Ensino Médio e BNCC: um cenário de disputas. Retratos da Escola, Brasília, v. 9, n. 17, p. 367-379, jul./dez. 2015

SILVA, Monica Ribeiro da. Impertinências entre trabalho, formação docente e o referencial de competências. Retratos da Escola, Brasília, v. 13, n. 25, p. 123-135, jan./maio 2019.

SILVA, Nara Suzana Pereira da; SELBACH, Paula Trindade da Silva. Política pública em educação: trilhando os caminhos da contemporaneidade até a implantação da Base Nacional Comum Curricular. RELACult - Revista Latino-Americana de Estudos em Cultura e Sociedade, Foz do Iguaçu, v. 4, n. 3, p. 1-10, set./dez. 2018.

SILVA, Rafaela Maiara Santos da. A ênfase nas competências e a formação da classe trabalhadora: divergências e contradições na Base Nacional Comum Curricular. Revista Educação e Políticas em Debate, Uberlândia, v. 9, n. 1, p. 208-227, jan./abr. 2020.

SILVA, Simone Gonçalves da; CANTARELLI, Juliana Mezomo. Justiça social e discurso neoliberal: problematizações sobre a Base Nacional Comum Curricular. Espaço Pedagógico, Passo Fundo, v. 26, n. 3, p. 777-794, set./dez. 2019.

SILVA, Suely Amaral Mello; SILVA, Greice Ferreira da. BNCC: um currículo integrador da infância brasileira? Debates em Educação, v. 8, n. 16, p. 66-88, jul./dez. 2016.

SILVA, Thaise da; ALVES, Andréia Vicência Vitor. A construção da Base Nacional Comum Curricular no Mato Grosso do Sul. Textura, Canoas, v. 22, n. 50, p. 118-139, abr./jun. 2020.

SOUSA, Joana Dark Andrade de; ARAGÃO, Wilson Honorato. A concepção de Currículo Nacional Comum no PNE: problematizações a partir do paradigma neoliberal. Espaço do Currículo (online), João Pessoa, v. 11, n. 1, p. 3-13, jan./abr. 2018.

SOUSA, Jorge Luis Umbelino de; PEREIRA, Maria Zuleide da Costa. Atuação da UNDIME na Base Nacional Comum Curricular: analisando articulações. Espaço do Currículo (online), João Pessoa, v. 12, n. 2, p. 352-363, maio/ago. 2019.

Revista de Estudios Teóricos y Epistemológicos en Política Educativa, v. 6, e2118101, p. 1-38, 2021 Disponible en: <https://www.revistas2.uepg.br/index.php/ retepe> 
A produção de conhecimento sobre a Base Nacional Comum Curricular no Brasil: levantamento...

SOUSA, Jorge Luis Umbelino de. Currículo e projetos de formação: Base Nacional Comum Curricular e seus desejos de performance. Espaço do Currículo (online), João Pessoa, v. 8, n. 3, p. 323-334, set./dez. 2015.

SOUSA, Raimunda Aurea Dias de; AMORIM, Alberto Filho Coelho. A Base Nacional Comum Curricular na contramão da educação no/do campo. Interfaces Científicas, Aracaju, v. 8, n. 3, p. 424-440, 2020.

SOUZA NETO, Alaim. Ensino médio em disputa: tensões engendradas em torno do currículo. e-Curriculum, São Paulo, v. 17, n. 3, p. 1263-1287, jul./set. 2019.

SOUZA NETO, Alaim. Projetos de ensino médio: disputas curriculares. Revista Espaço do Currículo (online), João Pessoa, v. 13, n. 2, p. 284-299, maio/ago. 2020.

SOUZA NETO, Alaim. Tensões no novo ensino médio: projetos de currículos em disputa. Retratos da Escola, Brasília, v. 13, n. 27, p. 699-714, set./dez. 2019.

SOUZA, Rachel Freire Torrez de. Os efeitos da BNCC na formação docente. Revista OKARA: Geografia em debate, João Pessoa, v. 12, n. 1, p. 69-79, 2018.

SOUZA, Sawana Araújo Lopes de; SOUSA, Maraiane Pinto de; ARAGÃO, Wilson Honorato. Dialogando sobre a BNCC, o currículo e a sua interferência para a formação de professores. RPGE- Revista on line de Política e Gestão Educacional, Araraquara, v. 24, n. 2, p. 412-424, maio/ago. 2020.

STANKEVECZ, Pricila de Fátima; CASTILlO, Noela Invernizzi. A construção da Base Nacional Comum Curricular na mídia: que atores e posições foram veiculados pelo jornal Folha de São Paulo? Horizontes, Itatiba, v. 36, n. 1, p. 31-48, jan./abr. 2018.

SUSSEKIND, Maria Luiza. A BNCC e o "novo" ensino médio: reformas arrogantes, indolentes e malévolas. Revista Retratos da Escola, Brasília, v. 13, n. 25, p. 91-107, jan./maio 2019.

SÜSSEKIND, Maria Luiza. As (im)possibilidades de uma Base Comum Nacional. e-Curriculum, São Paulo, v. 12, n. 3, p. 1512-1529, out./dez. 2014.

SUSSEKIND, Maria Luiza; MASKE, Jeferson. "Pendurando roupas nos varais": Base Nacional Comum Curricular, trabalho docente e qualidade. Em Aberto, Brasília, v. 33, n. 107, p. 173-187, jan./abr. 2020.

SUSSEKIND, Maria Luiza; PELLEGRINI, Raphael. "Não Existe Pecado do Lado de Baixo do Equador": políticas de currículo, direito à educação e as escritas nunca escritas. Cadernos de Pesquisa, São Luís, v. 23, n. especial, p. 43-56, set./dez. 2016.

TARLAU, Rebecca; MOELLER, Kathryn. O consenso por filantropia. Como uma fundação privada estabeleceu a BNCC no Brasil. Currículo sem Fronteiras, v. 20, n. 2, p. 553-603, maio/ago. 2020.

TREVISANI, Fernando de Mello; CORRÊA, Ygor. Ensino híbrido e o desenvolvimento de competências gerais da Base Nacional Comum Curricular. Revista Prâksis, Novo Hamburgo, ano 17, n. 2, p. 43-62, maio/ago. 2020.

TRICHES, Eliane de Fátima. ARANDA, Maria Alice de Miranda. A formulação da Base Nacional Comum Curricular (BNCC) como ação da política educacional; breve levantamento bibliográfico (2014-2016). Realização, Dourados, v. 3, n. 5, p. 81-98, 2016.

VARGAS, Janete Correia; ZANARDI, Isis Moraes; SANTOS, Eliane Aparecida Galvão dos; MARQUEZAN, Fernanda. A formação continuada de professores e os impactos da Base Nacional Comum Curricular: um olhar crítico para a reforma do Ensino Médio. Disciplinarum Scientia, Santa Maria, v. 18, n. 2, p. 429-443, 2017.

VERDÉRIO, Alex; BARROS, Adriana Junkerfeuerborn de. A educação do campo frente à Base Nacional Comum Curricular. Práxis Educativa, Ponta Grossa, v. 15, p. 1-16, 2020.

VIEIRA, Alexandro Braga; HERNADEZ-PILOTO, Sumika Soares de Freitas; RAMOS, Ines de Oliveira. Base Nacional Comum Curricular: tensões que atravessam a educação básica e a educação especial. Educação, Porto Alegre, v. 42, n. 2, p. 351-360, maio/ago. 2019.

VIEIRA, Jarbas Santos; FEIJÓ, José Roberto de Oliveira. A Base Nacional Comum Curricular e o conhecimento como commodity. Educação Unisinos, São Leopoldo, v. 22, n. 1, p. 35-43, jan./mar. 2018.

YBARRA, Luís Antônio Ccopa; SOARES, Marisa. A Base Nacional Comum Curricular e seus desdobramentos no ensino médio: um estudo comparado entre Brasil e Peru. Revista Temas em Educação, João Pessoa, Brasil, v. 27, n. 1, p. 108-127, jan./jun. 2018.

ZANARDI, Teodoro Adriano Costa. Qual é o lugar da base? Revista Educação e Políticas em Debate, Uberlândia, v. 8, n. 1, p. 5-18, jan./abr. 2019.

ZANATTA, Shalimar Calegari; BRANCO, Emerson Pereira; BRANCO, Alessandra Batista de Godoi; NEVES, Marcos Cesar Danhoni. Uma análise sobre a reforma do ensino médio e a implantação da Base Nacional Cumum Currícular no contexto das políticas neoliberais. e-Curriculum, São Paulo, v. 17, n. 4, p. 1711-1738, out./dez. 2019. ZITZKE, Viviane Aquino; PINTO, Elisane Ortiz de Tunes. A BNCC e os impactos no currículo do ensino médio integrado. Revista Thema, Pelotas, v. 17, p. 407-416, 2020.

\section{POLÍTICA CURRICULAR - Teses e Dissertações} Total: 31

Revista de Estudios Teóricos y Epistemológicos en Política Educativa, v. 6, e2118101, p. 1-38, 2021 Disponible en: <https://www.revistas2.uepg.br/index.php/retepe> 
AGOSTINI, Camila Chiodi. As artes de governar o currículo da educação infantil: a Base Nacional Comum Curricular em discussão. 2017. Dissertação (Mestrado em Interdisciplinar em Ciências Humanas) - Universidade Federal da Fronteira Sul, Erechim, 2017.

AMORIM, Alberto Filho de. BNCC (Base Nacional Comum Curricular) e a educação no/do campo: uma relação (in)consistente à realidade camponesa. 2019. Dissertação (Mestrado Profissional em Formação de Professores e Práticas Interdisciplinares) - Universidade de Pernambuco, Petrolina, 2019.

AVILA, Jaqueline Boeno D. As influências dos agentes públicos e privados no processo de elaboração da Base Nacional Comum Curricular. 2018. Dissertação (Mestrado em Educação) - Universidade Estadual do Centro-Oeste, Guarapuava, 2018.

BRANCO, Emerson Pereira. A implantação da BNCC no contexto das políticas neoliberais. 2017. Dissertação (Mestrado em Formação Docente Interdisciplinar) - Universidade Estadual do Paraná, Paranavaí, 2017. CENTENARO, Junior Bufon. Políticas educacionais e a formação de cidadãos razoáveis: uma análise reflexiva das competências gerais da BNCC. 2019. Dissertação (Mestrado em Educação) - Fundação Universidade de Passo Fundo, Passo Fundo, 2019.

CIERVO, Tassia Joana Rodrigues. A centralidade das competências socioemocionais nas políticas curriculares contemporâneas no Brasil. 2019. Dissertação (Mestrado em Educação) - Universidade do Vale do Rio dos Sinos, São Leopoldo, 2019.

COELHO, Eliane Siqueira costa. A BNCC e o processo de ensino e de aprendizagem nos anos iniciais do Ensino Fundamental: uma proposta definida por ações. 2019. Dissertação (Mestrado em Letras e Linguística) Universidade do Estado do Rio de Janeiro, São Gonçalo, 2019.

COSTA, Raquel da. Estado, políticas de educação e ensino: em debate a Base Nacional Comum Curricular (2015-2017). 2018. Dissertação (Mestrado em Formação Docente Interdisciplinar) - Universidade Estadual do Paraná, Paranavaí, 2018.

COSTA, Vanessa do Socorro Silva da. Base Nacional Comum Curricular como política de regulação do currículo, da dimensão global ao local: o que pensam os professores? 2018. Tese (Doutorado em Educação Currículo) - Pontifícia Universidade Católica de São Paulo, São Paulo, 2018.

HELENO, Carolina Ramos. Contribuição à crítica da Base Nacional Comum Curricular - a máscara do conformismo na educação do Banco Mundial. 2017. Dissertação (Mestrado em Educação) - Universidade Estadual de Feria de Santana, Feira de Santana, 2017.

LIMA, Maria Daniele Coelho. Os impactos da proposta da Base Nacional Comum Curricular para o ensino médio. 2019. Dissertação (Mestrado em Educação) - Centro Universitária Moura Lacerda, Ribeirão Preto, 2019.

LIMA, Meire Cardoso de. Base Nacional Comum Curricular (BNCC) para a Educação Infantil: estudo e implementação em uma creche do município de São Bernardo do Campo. 2020. Dissertação (Mestrado em Gestão e Práticas Educacionais) - Universidade Nove de Julho, São Paulo, 2020.

MACEDO, Edilene Nunes de. A percepção dos professores da cidade do Recife sobre as diretrizes Normativas da Base Nacional Comum Curricular (BNCC). 2018. Dissertação (Mestrado em Políticas Públicas) - Universidade Federal de Pernambuco, Recife, 2018.

MAIER, Thays Trindade. Avaliações em larga escala - Prova Brasil e prova ANA: análise das relações com a BNCC 2014-2019. 2020. Dissertação (Mestrado em Educação) - Universidade Estadual do Oeste do Paraná, Cascavel, 2020.

MEDEIROS, Ludmila Dimitrovicht de. Políticas públicas para a Educação Infantil: um estudo sobre a Base Nacional Comum Curricular (BNCC) na rede municipal de ensino de Londrina - PR. 2019. Dissertação (Mestrado em Educação) - Universidade Estadual de Londrina, Londrina, 2019.

MUELLER, Eduardo Ribeiro. A Base Nacional Comum Curricular no contexto da educação do campo: desencontros e contradições. 2018. Tese (Doutorado em Educação em Ciências e Matemática) - Universidade Federal de Mato Grosso, Cuiabá, 2018.

NAKAD, Fabricio Abdo. Desafios para a implementação da Base Nacional Comum Curricular. 2017. Dissertação (Mestrado em Gestão e Políticas Públicas) - Escola de Administração de Empresas de São Paulo, Fundação Getúlio Vargas, São Paulo, 2017.

OLIVEIRA, Juliana Duarte de. A reforma do Ensino Médio: mudança para melhor? Análise da reforma do ensino médio e proposta da Base Nacional Comum Curricular (BNCC). 2019. Dissertação (Mestrado Profissional em Processos de Ensino, Gestão e Inovação) - Universidade de Araraquara, Araraquara, 2019.

OLIVEIRA, Poliana Ferreira de. Políticas curriculares para a Educação Infantil: o caso da BNCC 2015-2017. 2019. Dissertação (Mestrado em Educação) - Universidade Estadual de Maringá, Maringá, 2019.

PAULA, Alessandra Valéria de. BNCC e os currículos subnacionais: prescrições indutoras das políticas educacionais e curriculares. 2020. Dissertação (Mestrado Profissional em Educação) - Universidade de Brasília, Brasília, 2020. 
A produção de conhecimento sobre a Base Nacional Comum Curricular no Brasil: levantamento...

PEREIRA, Karla Cristina Prudente. A BNCC do Ensino Médio e suas implicações para formação e trabalho dos professores. 2019. Dissertação (Mestrado em Formação Docente Interdisciplinar) - Universidade Estadual do Paraná, Paranavaí, 2019.

PIRES, Mônica Dias Medeiros. A influência empresarial na política curricular brasileira: um estudo sobre o Movimento pela Base Nacional Comum. 2020. Dissertação (Mestrado em Educação) - Faculdade de Educação, Universidade Federal de Juiz de Fora, Juiz de Fora, 2020.

ROCHA, Nathália Fernandes Egito. Base Nacional Comum Curricular e docência: discursos e significações. 2019. Tese (Doutorado em Educação) - Universidade Federal da Paraíba, João Pessoa, 2019.

ROCHA, Rosana Oliveira. Educação em Direitos Humanos em consonância com a Base Nacional Comum Curricular (BNCC). 2019. Dissertação (Mestrado Profissional em Educação: formação de formadores) Pontifícia Universidade Católica de São Paulo, São Paulo, 2019.

RODRIGUES, Vivian Aparecida da Cruz. A Base Nacional Comum Curricular em questão. 2017. Dissertação (Mestrado em Educação: Currículo) - Pontifícia Universidade Católica de São Paulo, São Paulo, 2017.

RORIZ, Ernani Oliveira Martins. A Base Nacional Comum Curricular e as influências neoliberais na sua construção. 2020. Dissertação (Mestrado em Educação) - Pontifícia Universidade Católica de Goiás, Goiânia, 2020. ROSA, Luciane Oliveira da. Continuidades e descontinuidades nas versões da BNCC para a Educação Infantil. 2019. Dissertação (Mestrado em Educação) - Universidade do Vale do Itajaí, Itajaí, 2019.

SILVA, Tiago Cortinaz da. A construção da Base Nacional Comum Curricular (BNCC) para a educação infantil e o ensino fundamental. 2019. Tese (Doutorado em Educação) - Universidade Federal do Rio Grande do Sul, Porto Alegre, 2019.

SILVA, Vanessa Silva da. Base Nacional Comum Curricular: uma análise crítica do texto da política. 2018. Dissertação (Mestrado em Educação) - Universidade Federal de Pelotas, Pelotas, 2018.

ZANGALLI, Irene. Recursos educacionais abertos no contexto da Base Nacional Comum Curricular para o ensino fundamental - anos iniciais. 2020. Dissertação (Mestrado Profissional em Educação e Novas Tecnologias) - Centro Universitário Internacional UNINTER, Curitiba, 2020.

ZANK, Debora Cristine Trindade. Base Nacional Comum Curricular e o "novo" ensino médio: análise a partir dos pressupostos teóricos da pedagogia histórico-crítica. 2020. Dissertação (Mestrado em Ensino) - Universidade Estadual do Oeste do Paraná, Foz do Iguaçu, 2020.

Fonte: Dados da pesquisa organizados pelo autor.

Quadro 2 - Trabalhos sobre BNCC vinculados à categoria Língua Portuguesa e Literatura

\section{LÍNGUA PORTUGUESA E LITERATURA - Artigos} Total: 34

ANDRADE, Carolina Santos Melo de; FERNANDES, Eliane Marquez da Fonseca; SOUZA, Maryá Amaral de. As tecnologias como ferramentas na educação linguística: a BNCC e a visão dos professores. Texto Livre: Linguagem e Tecnologia, Belo Horizonte, v. 12, n. 2, p. 30-46, maio 2019.

AZEVEDO, Isabel Cristina Michelan de; DAMACENO, Taysa Mercia dos Santos Souza. Desafios da BNCC em torno do ensino de língua portuguesa na educação básica. Revista de Estudos de Cultura, Aracaju, n. 7, p. 83-92, jan./abr. 2017.

BRUN, Edna Pagliari. A oralidade no ensino médio: uma análise da Base Nacional Comum Curricular. Entretextos, Londrina, v. 17, n. 1, p. 231-264, jan./jun. 2017.

BUSSE, Sanimar; ANDREOLLA, Evelin Stefanie Ferreira; FENILLI, Lays Maynara Favero. Reflexões sobre o trabalho com a diversidade linguística na Base Nacional Comum Curricular no componente língua portuguesa. Interfaces, Guarapuava, v. 11, n. 1, p. 12-23, 2020.

CABRAL, Ana Lúcia Tinoco; LIMA, Nelci Vieira de; ALBERT, Sílvia. TDIC na educação básica: perspectivas e desafios para as práticas de ensino de escrita. Trabalho de Linguística Aplicada, Campinas, n. 58, p. 1134-1163, set./dez. 2019.

CECHINEL, André. Literatura e atenção: notas sobre um novo regime de percepção no ensino de literatura.

Revista Brasileira de Educação, Rio de Janeiro, v. 24, p. 1-14, 2019.

CECHINEL, André. Semiformação literária: a instrumentalização da literatura na nova BNCC. Educação \& Realidade, Porto Alegre, v. 44, n. 4, p. 1-13, 2019.

DALVI, Maria Amélia. Criatividade na BNCC e em pesquisas atinentes à educação literária: indagações e desvelamentos. Desenredo, Passo Fundo, v. 15, n. 2, p. 283-300, maio/ago. 2019.

FURMAN, Evelyn Cardogna Nogueira; PETERMANN, Rafael. Uma leitura da disciplina de Língua Portuguesa na BNCC do ensino fundamental à luz dos estudos do letramento. Revista Mundi Sociais e Humanidades, Curitiba, v. 4, n. 2, p. 62-86, ago./ dez. 2019. 
FUZA, Ângela Francine Fuza; MIRANDA, Flávia Danielle Sordi Silva. Tecnologias digitais, letramentos e gêneros discursivos nas diferentes áreas da BNCC: reflexos nos anos finais do ensino fundamental e na formação de professores. Revista Brasileira de Educação, Rio de Janeiro, v. 25, p. 1-26, 2020

GERALDI, João Wanderley. O ensino de língua portuguesa e a Base Nacional Comum Curricular. Retratos da Escola, Brasília, v. 9, n. 17, p. 381-396, jul./dez. 2015.

JACOB, Ana Elisa; DIOLINA, Kátia; BUENO, Luzia. Os gêneros orais na penúltima versão da Base Nacional Comum Curricular: implicações para o ensino. Horizontes, Itatiba, v. 36, n. 1, p. 85-104, jan./abr. 2018.

MENDES, Nataniel. BNCC e o professor de literatura: água que corre entre pedras. Teias, Rio de Janeiro, v. 21, n. 63, p. 135-147, out./dez. 2020.

MENDONÇA, Fernanda de Quadros Carvalho; SOARES, Claudia Vivien Carvalho de Oliveira. Um breve olhar para a BNCC, as tecnologias digitais e a produção textual no ensino médio. Fólio, Vitória da Conquista, v. 12, n. 1, p. 1017-1039, jan./jun. 2020.

MOURA, Luana Medeiros de. Estudo de gênero discursivo: sequências didáticas e a Base Nacional Comum Curricular (BNCC). Journal Business Technology, Palmas, n. 12, p. 37-50, 2019.

NASCIMENTO, Antonio Naéliton do; ARAÚJO, Denise Lino de. A configuração teórica da produção textual na Base Nacional Comum Curricular: um olhar para a transposição didática. Revista Letras Raras, Campina Grande, v. 9, n. 2, p. 291-310, jun. 2020.

NASCIMENTO, Antonio Naéliton do; ARAÚJO, Denise Lino de. Transposição didática sobre o ensino de produção textual na BNCC. Espaço do Currículo (online), João Pessoa, v. 12, n. 2, p. 380-396, 2019.

PATRIOTA, Luciene Maria; PEREIRA, Paulo Ricardo Ferreira. O lugar da variação linguística na Base Nacional Comum Curricular (BNCC). Revista Letras Raras, Campina Grande, v. 7, n. 2, p. 289-307, 2018.

PEROVANO, Nayara Santos; SOUSA, Bárbara Cristina da Silva. Base Nacional Comum Curricular: a proposta de trabalho com a linguagem oral e escrita em diálogo. Cadernos da Fucamp, Campinas, v. 17, n. 30, p. 73-85, 2018. PINTON, Francieli Matzenbacher; VOLK, Romário; SCHMITT, Rosana Maria. A prática de análise linguística na BNCC e a perspectiva sociocultural de ensino e aprendizagem: (in)congruências teórico-metodológicas. Linguagem \& Ensino, Pelotas, v. 23, n. 2, p. 364-383, abr./jun. 2020.

PORTO, Ana Paula Teixeira; PORTO, Luana Teixeira. O espaço do texto literário na Base Nacional Comum Curricular na etapa do ensino fundamental. Signo, Santa Cruz do Sul, v. 43, n. 78, p. 13-23, set./dez. 2018.

RODRIGUES, Daniele Gualtieri. figurações da história da literatura no currículo escolar: o visível e o invisível na BNCC para o ensino médio. Nau Literária, Porto Alegre, v. 16, n. 2, p. 3-21, 2020.

RODRIGUES, Siane Gois Cavalcanti; SÁ, Cristina Manuela. A Base Nacional Comum Curricular brasileira e o lugar da fonética e da fonologia no ensino fundamental anos iniciais. Cadernos de Estudos Linguísticos, Campinas, v. 60, n. 3, p. 584-603, set./dez. 2018.

SILVA, Jéssica Rodrigues; ARAÚJO, Denise Lino de. O eixo análise linguística na BNCC: uma análise das linhas de continuidade entre diferentes versões da Base. Fólio, Vitória da Conquista, v. 12, n. 1, p. 1107-1130, jan./jun. 2020.

SILVA, Raquel Sousa da; MACÊDO, Jhennefer Alves; SEGABINAZI, Daniela Maria. A literatura juvenil no ensino fundamental II: avanços e recuos na Base Nacional Comum Curricular. Revista Estudos de Cultura, São Cristóvão, n. 7, p. 31-41, jan./abr. 2017.

SOARES, Denize Martins de Castro; ROSA, Ana Amélia Calazans. A Base Nacional Comum Curricular: considerações sobre o ensino de língua portuguesa e os multiletramentos. Revista do SELL, Uberaba, v. 7, n. 2, p. $1-22,2018$.

SOUSA FILHO, Sinval Martins de; MOURA, Luana Medeiros de. Propostas da Base Nacional Comum Curricular (BNCC) e de livros didáticos para o ensino da variação linguística no ensino fundamental anos finais. Journal Business Technology, Palmas, n. 16, p. 70-91, 2020.

SOUSA, Francisco Rafael Mota de. Desafios atuais para o ensino de gramática: reflexões sobre as habilidades de análise linguística/semiótica na Base Nacional Comum Curricular. Língu@Nostr@, Vitória da Conquista, v. 6, n. 2, p. 35-57, ago./dez. 2019.

SOUZA JUNIOR, Airton Santos de. Os parâmetros curriculares nacionais de língua portuguesa e a Base Nacional Comum Curricular: esclarecimentos acerca dos mitos de linguagem. Mandinga - Revista de Estudos Linguísticos, Redenção, v. 3, n. 2, p. 49-62, jul./dez. 2019.

SOUZA, Sweder. A língua portuguesa nos documentos de ensino brasileiro: um olhar sobre a Base Nacional Comum Curricular. Humanidades e Inovação, Palmas, v. 7, n. 7, p. 282-298, 2020.

STIEG, Vanildo; ALCÂNTARA, Regina Godinho de. O percurso histórico do ensino de língua portuguesa e os documentos oficiais: da Lei 5.692/71 à Base Nacional Comum Curricular (BNCC). Revista de Estudos de Cultura, São Cristóvão, n. 7, p. 15-29, jan. /abr. 2017.

STRIQUER, Marilúcia Santos Domingos. A BNCC e o papel do professor de língua portuguesa. The Especialist, São Paulo, v. 40, n. 1, p. 1-13, 2019.

Revista de Estudios Teóricos y Epistemológicos en Política Educativa, v. 6, e2118101, p. 1-38, 2021 Disponible en: <https://www.revistas2.uepg.br/index.php/retepe> 
A produção de conhecimento sobre a Base Nacional Comum Curricular no Brasil: levantamento...

TUSSI, Matheus Gazzola. Letramentos e gêneros discursivos jurídicos no ensino médio: possibilidades de estudo a partir da Base Nacional Comum Curricular. Revista Linguagem em Foco, Fortaleza, v. 12 n. 1, p. 41-54, 2020.

VIANA, Camila Rodrigues; SANTOS, Janete Silva dos. O leitor-literário entre os muros da escolarização: análise da (in)visibilidade da literatura infantil na BNCC. Revista Entreletras, Araguaína, v. 10, n. 2, p. 115-124, jul./dez. 2019.

\section{LÍNGUA PORTUGUESA E LITERATURA - Teses e Dissertações Total: 14}

FONTES, Nathalia Soares. A literatura na Base Nacional Comum Curricular: o ensino literário e a humanização do indivíduo. 2018. Dissertação (Mestrado em Educação) - Fundação Universidade Federal de Mato Grosso do Sul, Corumbá, 2018.

FRANCIO, Adriana Ciera Amaral. O ensino de língua portuguesa no Brasil: discursos materializados em documentos oficiais e atualizados pelo PCN e pela BNCC. 2019. Dissertação (Mestrado em Educação) Universidade Federal de São Carlos, São Carlos, 2019.

FREITAS, Henrique Campos. Análise contrastiva das circunstâncias de ângulo em corpus sobre a proposta da nova Base Nacional Comum Curricular: perspectivas a partir do Sistema de Avaliatividade. 2017. Dissertação (Mestrado em Estudos Linguísticos) - Universidade Federal de Uberlândia, Uberlândia, 2017.

GRANDO, Rafael Francisco Pellin. Uma unidade didática fundamentada na Base Nacional Comum Curricular para alunos do $5^{\circ}$ ano do ensino fundamental e suas dificuldades na produção textual. 2020. Dissertação (Mestrado em Letras) - Universidade Tecnológica Federal do Paraná, Pato Branco, 2020.

HITZSCHKY, Rayssa Araujo. Desenvolvimento de um Recurso Educacional Digital (RED) de língua portuguesa fundamentado na Base Nacional Comum Curricular. 2019. Dissertação (Mestrado em Educação) - Universidade Federal do Ceará, Fortaleza, 2019.

HUBER, Minea Carine. A leitura e a Base Nacional Comum Curricular (BNCC): uma abordagem pela perspectiva dos estudos culturais. 2017. Dissertação (Mestrado em Letras) - Universidade Regional Integrada do Alto Uruguai e das Missões, Frederico Westphalen, 2017.

LOURENCO, Delane Cristina Galiza. O eixo análise linguística/semiótica na BNCC: a natureza dos objetos de conhecimento para os anos finais do ensino fundamental. 2019. Dissertação (Mestrado em Linguagem e Ensino) - Universidade Federal de Campina Grande, Campina Grande, 2019.

MANSO, Guilherme Brambila. A produção de texto na era Enem: subjetividade e autoria no contexto políticopedagógico brasileiro contemporâneo. 2017. Dissertação (Mestrado em Educação) - Universidade Federal do Espírito Santo, Vitória, 2017.

MELO, Nathalia Niely Tavares Alves de. Representação social de professores de língua portuguesa sobre currículo no período de implantação da BNCC do ensino fundamental. 2019. Dissertação (Mestrado em Linguagem e Ensino) - Universidade Federal de Campina Grande, Paraíba, 2019.

NASCIMENTO, Maria Celia do. O ensino de escrita segundo a BNCC: transposição didática e proposta curricular para o ensino fundamental. 2018. Mestrado (Linguagem e Ensino) - Universidade Federal de Campina Grande, Campina Grande, 2018.

PEIXOTO, Mayara Carvalho. $\mathbf{O}$ conceito e a proposta de ensino de leitura na Base Nacional Comum Curricular (BNCC): desvelando processos de transposição didática externa. 2018. Dissertação (Mestrado em Linguagem e Ensino) - Universidade Federal de Campina Grande, Campina Grande, 2018.

ROCHA, Joelma de Souza. A Base Nacional Comum Curricular (BNCC): ensino de língua e política linguística. 2019. Dissertação (Mestrado em Estudos da Linguagem) - Universidade Estadual de Ponta Grossa, Ponta Grossa, 2019.

SA, Cassia Barros Casaes Nunes de. As práticas de linguagem nos PCN, na BNCC e nos livros didáticos. 2019. Dissertação (Mestrado Profissional em Letras) - Universidade Federal do Rio de Janeiro, Rio de Janeiro, 2019. SIQUEIRA, Luana Magalhães. BNCC para o Ensino Fundamental e práticas leitoras: gêneros digitais na sala de aula. 2019. Dissertação (Mestrado em Letras) - Universidade Regional Integrada do Alto Uruguai e das Missões, Frederico Westphalen, 2019.

Fonte: Dados da pesquisa organizados pelo autor.

Revista de Estudios Teóricos y Epistemológicos en Política Educativa, v. 6, e2118101, p. 1-38, 2021 Disponible en: <https://www.revistas2.uepg.br/index.php/retepe> 
Quadro 3 - Trabalhos sobre BNCC vinculados à categoria Matemática

\section{MATEMÁTICA - Artigos \\ Total: 34}

AZEVEDO, Marcos Cruz de; MELO, Elaine Alves Santos; SIQUEIRA, Angelo Santos. Livros didáticos de matemática de sexto e sétimo ano do plano nacional de livros didáticos 2017-2019: uma análise da utilização de gêneros textuais a partir das versões iniciais da Base Nacional Comum Curricular. Revista UNIABEU, Nova Iguaçu, v. 11, n. 29, p. 311-335, set./dez. 2018.

BONI, Giovanna Ellen Oliveira; ALENCAR, Edvonete Souza de. "Ou isto ou aquilo": comparativo entre a matemática da educação infantil nas diretrizes e na Base Nacional Comum Curricular. Revista Insignare Scientia, Chapecó, v. 1, n. 3, p. 1-20, set./dez. 2018.

CARRETA, Cecy Leite Alves; SANTOS, Cintia Aparecida Bento dos. Background, foreground e a educação matemática crítica: uma investigação da Base Nacional Comum Curricular do Ensino Fundamental. Revista Paranaense de Educação Matemática, Campo Mourão, v. 8, n. 17, p. 248-264, jul./dez. 2019.

COSTA, Renato Pinheiro da; SOUSA, Camila; CORDEIRO, Leonardo Zenha. O ensino de matemática na Base Nacional Comum Curricular nos anos finais do ensino fundamental. Ensino Em Re-Vista, Uberlândia, v. 27, n. 2, p. 572-594, maio/ago. 2020.

CZIGEL, Érica; MONDINI, Fabiane; PAVANELO, Elisangela. A Base Nacional Comum Curricular (BNCC) e a organização da matemática no ensino fundamental. Revista Pesquisa Qualitativa, São Paulo, v. 7, n. 15, p. 356369, 2019.

D'ALMEIDA, Joice; BIANCHINI, Barbara Lutaif. A teoria elementar dos números nos PCN e na BNCC: um estudo comparativo. Revista de Produção Discente em Educação Matemática, São Paulo, v. 8, n. 2, p. 103113, 2019.

FAVERO, Débora Cristina Borba Pereira; MANRIQUE, Ana Lúcia. As mudanças geradas pela Base Nacional Comum Curricular na abordagem do pensamento algébrico nos anos iniciais do ensino fundamental. Revista de Produção Discente em Educação Matemática, São Paulo, v. 9, n. 1, p. 89-101, 2020.

FERREIRA, João Socorro Pinheiro. Atividades de metodologias ativas para matemática com elementos didáticos da BNCC. Revista Brasileira de Pós-Graduação, Brasília, v. 16, n. 35, p. 1-22, 2020.

FERREIRA, Weberson Campos; LEAL, Marcia Rodrigues; MOREIRA, Geraldo Eustáquio. Early algebra e Base Nacional Comum Curricular: desafios aos professores que ensinam matemática. REVEMAT, Florianópolis, v. 15, n. 1, p. 1-21, 2020.

GIORDANO, Cassio Cristiano; ARAÚJO, José Ronaldo Alves; COUTINHO, Cileda de Queiroz e Silva. Educação estatística e a Base Nacional Comum Curricular: o incentivo aos projetos. REVEMAT, Florianópolis, v. 14, p. 120, edição especial educação estatística, 2019.

GIORDANO, Cassio Cristiano; ASSIS, Marco Rodrigo da Silva; COUTINHO, Cileda de Queiroz e Silva. A educação financeira e a Base Nacional Comum Curricular. Em Teia, João Pessoa, v. 10, n. 3, p. 1-20, 2019.

HECK, Miriam Ferrazza. Considerações sobre a Base Nacional Comum Curricular (BNCC) e as unidades de conhecimento matemático. Revista Eletrônica Científica Ensino Interdisciplinar, Natal, v. 5, n. 13, p. 56-70, fev. 2019

JANISCH, Adriane Beatriz Liscano; JELINEK, Karin Ritter. Explorando a educação financeira no ensino fundamental: um estudo de possibilidades a partir das orientações da BNCC. Brazilian Journal of Development, São José dos Pinhais, v. 6, n. 7, p. 48324-48342, jul. 2020.

KIPPER, Daiane; OLIVEIRA, Cláudio José de; GOMES, Lívia Bittencourt. Competências matemáticas na BNCC: implicações curriculares. Revista Práxis Educacional, Vitória da Conquista, v. 15, n. 34, p. 53-74, edição especial, 2019.

KUHN, Malcus Cassiano; PEREIRA, Jesiane de Freitas. A multiplicação nos anos iniciais do ensino fundamental: da teoria para a prática. Revista Thema, Pelotas, v. 17, n. 2, p. 464-482, 2020.

PASSOS, Cármen Lúcia Brancaglion; NACARATO, Adair Mendes. Trajetória e perspectivas para o ensino de matemática nos anos iniciais. Estudos Avançados, São Paulo, v. 32, n. 94, p. 119-135, 2018.

PAULA, Vanessa Sena de. Um diálogo matemático entre Base Nacional Comum Curricular e a proposta curricular de Guarulhos - QSN. Revista Educação, Guarulhos, v. 14, n. 1, p. 61-68, 2019.

PERTILE, Karine; JUSTO, Jutta Cornelia Reuwsaat. O desafio dos professores dos anos iniciais para o ensino da matemática conforme a BNCC. Ensino Em Re-Vista, Uberlândia, v. 27, n. 2, p. 612-636, 2020.

PESSOA, Cristiane Azevedo dos Santos; MUNIZ JUNIOR, Ivail; KISTEMANN JR, Marco Aurélio. Cenários sobre educação financeira escolar: entrelaçamentos entre a pesquisa, o currículo e a sala de aula de Matemática. Em Teia, João Pessoa, v. 9, n. 1, p. 1-28, 2018. 
A produção de conhecimento sobre a Base Nacional Comum Curricular no Brasil: levantamento...

PINHEIRO, Maria Gracilene de Carvalho; SILVA, Angélica da Fontoura Garcia; GALVÃO, Maria Elisa Esteves Lopes. Dos PCN à BNCC: uma análise interpretativa das indicações de aprendizagens no tema probabilidade. Revista Paranaense de Educação Matemática, Campo Mourão, v. 9, n. 18, p. 137-151, jan./jun. 2020.

PINTO, Antonio Henrique. A Base Nacional Comum Curricular e o Ensino de Matemática: flexibilização ou engessamento do currículo escolar. Bolema, Rio Claro, v. 31, n. 59, p. 1045-1060, 2017.

PONTES, Marcio Matoso de; VASCONCELOS, Francisco Vilar; LIMA, Dina Séfora Santana Menezes; VANCONCELOS, Ana Karine Portela. A temática 'Probabilidade e Estatística' nos anos iniciais do ensino fundamental a partir da promulgação da BNCC: percepções pedagógicas. Educitec, Manaus, v. 5, n. 12, p. 221237, 2019.

ROLKOUSKI, Emerson. Dos direitos de aprendizagem e do pacto nacional pela alfabetização na idade certa à Base Nacional Comum Curricular: o caso da alfabetização matemática. Horizontes, Itatiba, v. 36, n. 1, p. 119-131, jan./abr. 2018.

SAMÁ, Suzi; SILVA, Rejane Conceição Silveira da. Probabilidade e estatística nos anos iniciais do ensino fundamental a partir da Base Nacional Comum Curricular. Zetetiké, Campinas, v. 28, p. 1-21, 2020.

SANTANA, Claudenia da Silva. O desafio de trabalhar os jogos matemáticos e a BNCC na era digital no Ensino Fundamental. Brazilian Journal of Development, São José dos Pinhais, v. 6, n. 1, p. 28-40, jan. 2020.

SANTOS, Márcio Eugen Klingenschmid Lopes dos; LUZ, Jefferson Oliveira Cristovão da; MARTINS, Priscila Bernardo. A utilização de metodologias ativas no processo de ensino/aprendizagem de Matemática alinhadas a Base Nacional Comum Curricular. Research, Society and Development, Itajaí, v. 9, n. 5, p. 1-13, 2020

SANTOS, Maria José Costa dos. O currículo de matemática dos anos iniciais do ensino fundamental na Base Nacional Comum Curricular (BNCC): os subalternos falam? Horizontes, Itatiba, v. 36, n. 1, p. 132-143, jan./abr. 2018.

SANTOS, Wagner Dias; SANTOS JUNIOR, Jorge dos; VELASQUE, Luciane de Souza. O Desenvolvimento do Letramento Estatístico pelos Didáticos e a Base Nacional Comum Curricular. Revista de Ensino de Ciências e Matemática - REnCiMa, São Paulo, v. 9, n. 2, p. 210-229, 2018.

SCREMIN, Greice; RIGHI, Flávia Pereira. Ensino de álgebra no ensino fundamental: uma revisão histórica dos PCN à BNCC. Ensino Em Re-Vista, Uberlândia, v. 27, n. 2, p. 409-433, maio/ago. 2020.

SILVA, Lucenildo Elias da. Educação matemática e a Base Nacional Comum Curricular (BNCC): um desafio para a educação básica. Revista Humanidades e Inovação, Palmas, v. 6, n. 6, p. 51-61, 2019.

SOUZA, Matheus dos Santos; DIAS, Marcelo de Oliveira. A Base Nacional Comum Curricular e o uso das tecnologias na educação matemática: discursos da reforma curricular. Espaço do Currículo (online), João Pessoa, v. 13, n. 1, p. 233-251, 2020.

STURION, Brena Cristina; AMARAL-SCHIO, Rúbia Barcelos. BNCC do Ensino Médio: um olhar sobre os conteúdos de área e volume nos livros didáticos de matemática. Tangram - Revista de Educação Matemática, Dourados, v. 2 n. 3, p. 88-102, 2019.

VARGAS, Andressa Franco; LEIVAS, José Carlos Pinto; LARA, Débora da Silva de. Investigação matemática como recurso metodológico para o ensino de geometria nos anos iniciais. Revista Insignare Sciencia, Chapecó, v. 2 , n. 4 , p. $258-277$, set./dez. 2019.

VILAS BÔAS, Sandra Gonçalves; CONTI, Keli Cristina. Base Nacional Comum Curricular: um olhar para estatística e probabilidade nos anos iniciais do ensino fundamental. Ensino Em Re-Vista, Uberlândia, v. 25, p. 984-1003, n. especial, 2018.

\section{MATEMÁTICA - Teses e Dissertações Total: 8}

BOTELHO, Janaina Alves. Os recursos livro didático e a BNCC no planejamento de aulas do professor de matemática do Ensino Fundamental. 2019. Dissertação (Mestrado Profissional em Ensino de Ciências e Matemática) - Universidade Estadual da Paraíba, Campina Grande, 2019.

CORREA, Rosilene Periera de Oliveira. Construções geométricas: uma proposta de ensino utilizando régua, compasso e dobraduras. 2020. Dissertação (Mestrado Profissional em Matemática) - Universidade Federal de Juiz de Fora, Juiz de Fora, 2020.

FAVERO, Débora Cristina Borba Pereira. As mudanças geradas pela Base Nacional Comum Curricular (BNCC) em uma coleção de livros didáticos para o ciclo de alfabetização na abordagem do pensamento algébrico. 2020. Dissertação (Mestrado em Educação: Matemática) - Pontifícia Universidade Católica de São Paulo, São Paulo, 2020.

PAIVA, Antonia Vanda de. Base Nacional Comum Curricular: uma reflexão sobre a formação continuada de docentes que ensinam matemática nos anos finais do ensino fundamental. 2019. Dissertação (Mestrado Profissional em Ensino de Ciências e Matemática) - Universidade Cruzeiro do Sul, São Paulo, 2019. 
REGONHA, Mariane Rodrigues. Matemática financeira: uma proposta utilizando a BNCC. 2019. Dissertação (Mestrado Profissional em Matemática) - Universidade Estadual Paulista Júlio de Mesquita Filho, Rio Claro, 2019. SANTOS JUNIOR, Jorge dos. Letramento estatístico nos livros dos anos finais do ensino fundamental e a Base Nacional Comum Curricular. 2017. Dissertação (Mestrado Profissional em Matemática) - Universidade Federal do Estado do Rio de Janeiro, Rio de Janeiro, 2017.

SANTOS, Wagner Dias. Letramento estatístico nos livros de ensino médio e a Base Nacional Comum Curricular. 2017. Dissertação (Mestrado Profissional em Matemática) - Universidade Federal do Estado do Rio de Janeiro, Rio de Janeiro, 2017.

SILVA, Alison Luan Ferreira da. História da matemática, tecnologias digitais e investigação matemática no ensino de unidades temáticas de matemática da BNCC para o $\mathbf{8}^{\mathbf{0}}$ Ano. 2019. Dissertação (Mestrado Profissional em Ensino de Ciências Naturais e Matemática) - Universidade Federal do Rio Grande do Norte, Natal, 2019.

Fonte: Dados da pesquisa organizados pelo autor.

Quadro 4 - Trabalhos sobre BNCC vinculados à categoria Fundamentos

\section{FUNDAMENTOS - Artigos}

Total: 29

ANDRADE, Maria Carolina Píres de; GAWRYSZEWSKI, Bruno. Desventuras da educação brasileira e as 'reformas' atuais: educar para a produtividade do trabalho. EccoS Revista Científica, São Paulo, n. 47, p. 105-125, 2018.

ANDRADE, Maria Carolina Pires de; MOTTA, Vânia Cardoso da. Base Nacional Comum Curricular e o novo ensino médio: uma análise à luz de categorias de Florestan Fernandes. Revista HISTEDBR On-line, Campinas, v. 20, p. 1-26, 2020 .

CÂNDIDO, Rita de Kássia; GENTILINI, João Augusto. Base Curricular Nacional: reflexões sobre autonomia escolar e o projeto Político-pedagógico. RBPAE - Revista Brasileira de Política e Administração da Educação, Porto Alegre, v. 33, n. 2, p. 323-336, maio/ago. 2017.

CARVALHO, Janete Magalhães; SILVA, Sandra Kretli da; DELBONI, Tânia Mara Zanotti Guerra Frizzera. A Base Nacional Comum Curricular e a produção biopolítica da educação como formação de "capital humano". eCurriculum, São Paulo, v. 15, n. 2, p. 481-503, abr./jun. 2017.

CORAZZA, Sandra Mara. Base Nacional Comum Curricular: apontamentos crítico-clínicos e um trampolim. Educação, Porto Alegre, v. 39, n. esp. (supl.), p. 135-144, dez. 2016.

COSSETIN, Vânia Lisa Fischer. Uma leitura ambivalente sobre a adoção de uma Base Curricular Nacional: para fazer justiça à reflexividade da filosofia da educação. Educar em Revista, Curitiba, n. 66, p. 295-311, out./dez. 2017.

DOMINGOS, Rafael Oliveira da Costa. Educação técnica e as mudanças da metodologia SENAI após a BNCC. Revista Científica Novas Configurações - Diálogos Plurais, Luziânia, v. 1, n. 1, p. 52-57, 2020.

DUARTE, Ana Lucia Cunha; SILVA, Renato Moreira; MOURA, Neria. Concepção de competência na BNCC e no Documento Curricular do Território Maranhense (DCTM). Educação em Revista, Marília, v. 21, n. 2, p. 21 36, 2020.

ERNESTO, Talita da Silva et al. Da Base Nacional Comum Curricular à didática do docente: tessituras normativas da educação do século XXI. Interdisciplinary Scientific Journal, Rio de Janeiro, v. 6, n. 2, p. 89-109, abr./jun. 2019.

GONÇALVES, Amanda Melchiotti; DEITOS, Roberto Antonio. Competências gerais da Base Nacional Comum Curricular (BNCC): fundamentos teóricos e ideológicos. EccoS Revista Científica, São Paulo, n. 52, p. 1-19, jan./mar. 2020.

LIMA, Letícia Aparecida Alves de; SILVA, Marcus Vinicius Gonçalves da. Ensino por competências na educação básica: proposta de um instrumento de avaliação de conteúdo. Research, Society and Development, Itajaí, v. 9, n. 6 , p. $1-10,2020$.

LIMA, Maria de Fátima Teixeira; SOBREIRA, Mariza Danielli Pereira; OLINDA, Sahmaroni Rodrigues de. A Base Nacional Comum Curricular: uma abordagem sobre currículo conhecimento. Id on Line Revista Multidisciplinar e de Psicologia, Jaboatão dos Guararapes, v. 13, n. 48, p. 230-242, (supl.). dez. 2019.

MACEDO, Roberto Sidnei; NASCIMENTO, Claudio Orlando do; GUERRA, Denise de Moura. Heterogeneidade, experiência e currículo: contrapontos à ideia de Base Comum Nacional e à vontade de exterodeterminação da formação. e-Curriculum, São Paulo, v. 12, n. 3, p. 1556-1569, 2014.

MANFRÉ, Ademir Henrique. Base Nacional Comum Curricular e (semi)formação: quais os dilemas da escola atual? Contexto \& Educação, Ijuí, ano 35, n. 111, p. 9-28, maio/ago. 2020.

Revista de Estudios Teóricos y Epistemológicos en Política Educativa, v. 6, e2118101, p. 1-38, 2021 Disponible en: < https:/ /www.revistas2.uepg.br/index.php/ retepe> 
A produção de conhecimento sobre a Base Nacional Comum Curricular no Brasil: levantamento...

MELLO, Joana Cândida Pinheiro Lima de; LIMA, Roberta Valéria Guedes de; MOREIRA, Jonathan Rosa. Base Nacional Comum Curricular e as concepções pedagógicas da educação básica. Revista Projeção e Docência, Brasília, v. 9, n. 2, p. 26-41, 2018.

MELO, Alessandro de.; MAROCHI, Ana Claudia. Cosmopolitismo e performatividade: categorias para uma análise das competências na Base Nacional Comum Curricular. Educação em Revista, Marília, v. 35, p. 1-23, 2019.

NEITZEL. Odair; SCHWENGBER, Ivan Luís. Os conceitos de capacidade, habilidade e competência e a BNCC. Revista Educação e Emancipação, São Luís, v. 12, n. 2, p. 210-227, maio/ago. 2019.

NORNHA, Ana Carolina Cortez. Considerações semióticas sobre o uso da tecnologia digital em salas de aula. Estudos Semióticos, São Paulo, v. 15, n. 2, p. 280-291, dez. 2019.

OLIVEIRA, Eliane Alves de. Como trabalhar o repertório cultural dos alunos e a comunicação conforme proposta da BNCC a partir da cultura afrodescendente? ODEERE Vitória Conquista, v. 5, n. 9, p. 457-473, jan./jun. 2020.

PAZ, Danielle de Paiva Vilela. A formação implícita e explícita na Base Nacional Comum Curricular. Revista Com Censo, Brasília, v. 6, n. 2, p. 63-72, maio 2019.

PINA, Leonardo Docena; GAMA, Carolina Nozella. Base Nacional Comum Curricular: algumas reflexões a partir da pedagogia histórico-crítica. Trabalho Necessário, Rio de Janeiro, v. 18, n. 36, p. 78-102, 2020.

RIBEIRO, William de Goes. Utopias e regulações de uma Base Nacional Comum Curricular: projeções ficcionais para juventudes ideais. Espaço do currículo (online), João Pessoa, v. 12, n. 1, p. 195-208, jan./abr. 2019.

SANTOS, Eliane Marques dos. Ensino e aprendizagem das competências e habilidades da Base Nacional Comum Curricular. Diversitas Journal, Maceió, v. 5, n. 4, p. 3293-3308, out./dez. 2020.

SANTOS, Emina; TOMÉ, Luane. O discurso ausente de democracia na Base Nacional Comum Curricular do ensino fundamental. Jornal de Políticas Educacionais, Curitiba, v. 14, n. 25, p. 1-19, maio 2020.

SARAIVA, Gabriela Luz; ZUCOLOTTO, Marcele Pereira da Rosa. A Pedagogia Waldorf e a Base Nacional Comum Curricular na Formação da Criança. Research, Society and Development, Itajaí, v. 9, n. 10, p. 1-16, 2020.

SILVA, Rafael Bianchi; SILVA, Guilherme Elias da. Fundamentos formativos da Base Nacional Curricular Comum (BNCC): uma análise a partir de Zygmunt Bauman. Educação, Santa Maria, v. 45, p. 1-22, 2020.

SILVA, Sandra Kretli da; DELBONI, Tania Mara Zanotti Guerra Frizzera. Cotidiano escolar como laboratório de existência: lugar de criação, experimentação e invenção. Espaço do Currículo, João Pessoa, v. 9, n. 3, p. 404-411, set./dez. 2016.

SOAVE, Cláudia; BARBIERI, Simone Corte Real; ROSA, Geraldo Antonio da. Ética como espaço de voz e ressonâncias do cuidado de si docente na escola pública e na Base Nacional Comum Curricular. Revista Educação em Questão, Natal, v. 58, n. 56, p. 1-23, abr./jun. 2020.

TEDESCO, Anderson Luiz; SCHWENGBER, Ivan Luís. De Husserl a Freire: reflexões sobre o conceito de competência na Base Nacional Comum Curricular. Revista de Estudios Teóricos y Epistemológicos en Política Educativa, Ponta Grossa, v. 5, p. 1-12, 2020.

\section{FUNDAMENTOS - Teses e Dissertações Total: 15}

BACK, Jeizi Loici. Normatização dos corpos pela escola: uma análise da BNCC. 2020. Dissertação (Mestrado em Educação) - Universidade Estadual do Oeste do Paraná, Cascavel, 2020.

BRAZAO, Diogo Alchorne. Entre o colonial e o decolonial: A Base Nacional Comum Curricular como território de disputas. 2018. Dissertação (Mestrado em História Social) - Universidade do Estado do Rio de Janeiro, São Gonçalo, 2018.

CARDOSO, Marlon Magno Rangel. Educação e ensino médio: identidades juvenis e o currículo para as juventudes. 2019. Dissertação (Mestrado em Educação) - Universidade Federal do Tocantins, Palmas, 2019.

COUBE, Andre Luiz da Silva. A Base Nacional Comum Curricular como ciclo contínuo de políticas e produção cotidiana de epistemicídios. 2019. Dissertação (Mestrado em Educação) - Universidade Federal do Estado do Rio de Janeiro, Rio de Janeiro, 2019.

FONSECA, Daniel José Rocha. Análise discursiva sobre a Base Nacional Comum Curricular. 2018. Dissertação (Mestrado em Educação) - Universidade Federal de Goiás, Jataí, 2018.

FREITAS, João Paulo Cardoso de. Narrativas acerca da educação científica e articulações com a Base Nacional Comum Curricular. 2018. Dissertação (Mestrado em Educação) - Universidade Estadual de Campinas, Campinas, 2018.

GOMES, Fabrício Augusto. Base Nacional Comum Curricular do ensino médio: currículo, poder e resistência. 2019. Tese (Doutorado em Educação) - Pontifícia Universidade Católica de Goiás, Goiânia, 2019.

GONÇALVES, Amanda Melchiotti. Os intelectuais orgânicos da Base Nacional Comum Curricular (BNCC): aspectos teóricos e ideológicos. 2020. Dissertação (Mestrado em Educação) - Universidade Estadual do Oeste do Paraná, Cascavel, 2020.

Revista de Estudios Teóricos y Epistemológicos en Política Educativa, v. 6, e2118101, p. 1-38, 2021 Disponible en: <https://www.revistas2.uepg.br/index.php/retepe> 
RIBEIRO, Natalia de Vasconcelos Cordeiro Telles. Temas contemporâneos e transversais na BNCC: as contribuições da transdisciplinaridade. 2019. Dissertação (Mestrado em Educação) - Universidade Católica de Brasília, Brasília, 2019.

ROCHA, Nathalia Fernandes Egito. Base Nacional Comum Curricular e micropolítica: analisando os fios condutores. 2016. Dissertação (Mestrado em Educação) - Universidade Federal da Paraíba, João Pessoa, 2016.

SALATIEL, Tarcisio Francisco Oliveira. O trabalho prescrito pela Base Nacional Comum Curricular no eixo de análise linguística sob a visão sociointeracionista. 2019. Dissertação (Mestrado em Linguística Aplicada) Universidade do Vale do Rio dos Sinos, São Leopoldo, 2019.

SANTOS, Gisele da Silva. Vozes que constituem o discurso da igualdade educacional na Base Nacional Comum Curricular Brasileira. 2019. Dissertação (Mestrado em Educação) - Universidade Federal da Fronteira Sul, Chapecó, 2019.

SANTOS, Rivia de Jesus. Análise dos discursos sobre relações (inter) étnicas em entremeio com a Base Nacional Comum Curricular - BNCC. 2019. Dissertação (Mestrado em Educação) - Universidade Estadual do Sudoeste da Bahia, Vitória da Conquista, 2019.

SOUZA, Alice Moraes Rego de. Base Nacional Comum para quê/quem? Uma cartografia de conflitos discursivos na produção de currículo oficial. 2019. Tese (Doutorado em Estudos de Linguagem) - Universidade Federal Fluminense, Niterói, 2019.

ZWIRTES, Polyana. A Base Nacional Curricular - uma análise à luz da sociolinguística educacional. 2020. Dissertação (Mestrado em Ensino) - Universidade Estadual do Oeste do Paraná, Foz do Iguaçu, 2020.

Fonte: Dados da pesquisa organizados pelo autor.

Quadro 5 - Trabalhos sobre BNCC vinculados à categoria Ciências

\section{CIÊNCIAS - Artigos}

Total: 27

BARROSO, Maria Cleide da Silva et al. Base Nacional Comum Curricular e as transformações na área das ciências da natureza e tecnologias. Research, Society and Development, Itajaí, v. 9, n. 2, p. 1-14, 2020.

BELTRÃO, Glenda Gabriele Bezerra; AGUIAR, José Vicente de Souza. a concepção de saúde-doença nos anos iniciais do ensino fundamental: uma abordagem histórica. REAMEC, Manaus, v. 7, n. 3, p. 53-76, set./dez. 2019.

BENASSI, Cassiane Beatrís Pasuck; FERREIRA, Mariane Grando; STRIEDER, Dulce Maria. A Base Nacional Comum Curricular (BNCC) e a epistemologia de Paul Karl Feyerabend no ensino de ciências: questões terminológicas. Horizontes, Dourados, v. 8, n. 15, p. 20-38, jan./jun. 2020.

BURCHARD, Camila Pereira et al. Análise da temática saúde na Base Nacional Comum Curricular. Research, Society and Development, Itajaí, v. 9, n. 7, p. 1-14, 2020.

CABRAL, Lucas Munhoz; JORDÃO, Rosana dos Santos. Base Nacional Comum Curricular: ciências e multiculturalismo. e-Curriculum, São Paulo, v. 18, n. 1, p. 111-136, jan./mar. 2020

CASTRO, Flávia Pierrotti de; MIRANDA, Marcos César Rodrigues de; SILVA, Renan Antônio da; MARQUES, Rosebelly Nunes. A construção do conhecimento científico na Base Nacional Comum Curricular. Interfaces Científicas - Educação, Aracaju, v. 9, n. 1, p. 107-118, 2020.

DESIDÉRIO, Ricardo. A exclusão da temática sexualidade nos anos iniciais do ensino fundamental na BNCC e seus reflexos para o ensino de ciências. Horizontes, Dourados, v. 8, n. 15, p. 98-112, jan./jun. 2020.

FLÔR, Cristhiane Carneiro Cunha; TRÓPIA, Guilherme. Um olhar para o discurso da Base Nacional Comum Curricular em funcionamento na área de ciências da natureza. Horizontes, Dourados, v. 36, n. 1, p. 144-157, jan./abr. 2018.

FRANCO, Luiz Gustavo; MUNFORD, Danusa. Reflexões sobre a Base Nacional Comum Curricular: um olhar da área de ciências da natureza. Horizontes, Dourados, v. 36, n. 1, p. 158-170, jan./abr. 2018.

GOUVEIA, Cristiane Talita Gromann de; GOUVEIA-NETO, Sérgio Candido de. O ensino de ciências nos anos iniciais do ensino fundamental: uma proposta metodológica a partir da BNCC. Horizontes, Dourados, v. 8, n. 15, p. 39-60, jan./jun. 2020.

HILARIO, Thiago Wedson; CHAGAS, Helaíny Wanyessy Kenya Rodrigues Silva. O ensino de ciências no ensino fundamental: dos PCNs à BNCC. Brazilian Journal of Development, São José dos Pinhais, v. 6, n. 9, p. $65687-$ 65695, set. 2020.

LEITE, Rosana Franzen; RITTER, Olga Maria Schimidt. Algumas representações de ciências na BNCC - Base Nacional Comum Curricular: área de ciências da natureza. Temas \& Matizes, Cascavel, v. 11, n. 20, p. 1-7, jan./jun. 2017.

MARCONDES, Maria Eunice Ribeiro. As ciências da natureza nas $1^{\text {a }}$ e $2^{\mathrm{a}}$ versões da Base Nacional Comum Curricular. Estudos Avançados, São Paulo, v. 32, n. 94, p. 269-284, 2018.

Revista de Estudios Teóricos y Epistemológicos en Política Educativa, v. 6, e2118101, p. 1-38, 2021 Disponible en: <https://www.revistas2.uepg.br/index.php/retepe> 
A produção de conhecimento sobre a Base Nacional Comum Curricular no Brasil: levantamento...

MARIANI, Vanessa de Cassia Pistóia; SEPEL, Lenira Maria Nunes. Olhares docentes: caracterização do ensino de ciências em uma rede municipal de ensino perante a BNCC. RBECM, Passo Fundo, v. 3, n. 1, p. 48-75, jan./jun. 2020.

MUNERATTO, Felipe et al. A constituição do grupo de elaboração da BNCC de ensino de ciências: trajetórias de seus atores sociais e seus impactos na elaboração da proposta. Horizontes, Dourados, v. 8, n. 15, p. 113-132, jan./jun. 2020.

MUNFORD, Danusa. Múltiplos contextos que interpelam o componente curricular de ciências da natureza para os anos iniciais do ensino fundamental na BNCC. Em Aberto, Brasília, v. 33, n. 107, p. 127-140, jan./abr. 2020.

PICCININI, Cláudia Lino; ANDRADE, Maria Carolina Pires de. O ensino de ciências da natureza nas versões da Base Nacional Comum Curricular, mudanças, disputas e ofensiva liberal-conservadora. REnBio, Florianópolis v. 11, n. 2, p. 34-50, 2018.

REIS, Geilson de Arruda; CAVALCANTE, Lígia Vieira da Silva; OLIVEIRA, Eniz Conceição. O conceito de alfabetização científica e a possibilidade de interações entre cinco competências gerais da Base Nacional Comum Curricular - BNCC. Research, Society and Development, Itajaí, v. 9, n. 8, p. 1-13, 2020.

RODRIGUES, Paloma Alinne Alves. Um desafio para a Base Nacional Comum Curricular: o diálogo entre a alfabetização científica e tecnológica e a inclusão escolar. Horizontes, Dourados, v. 8, n. 15, p. 150-160, jan./jun. 2020.

RODRIGUES-MOURA, Sebastião; GONÇALVES, Terezinha Valim Oliver. Por uma cultura científica para a incorporação social da ciência: implantações curriculares na BNCC. Horizontes, Dourados, v. 8, n. 15, p. 133-149, jan./jun. 2020.

SANTOS, Adriana Ramos dos; RIBEIRO, Letícia Mendonça Lopes. A Base Nacional Comum Curricular e suas implicações na proposta curricular de ciências naturais do estado do Acre. Horizontes, Dourados, v. 8, n. 15, p. 81-97, jan./jun. 2020.

SANTOS, Marina Silveira Bonacazata; MOREIRA, Jani Alves da Silva. Políticas curriculares na BNCC e o ensino das ciências da natureza e suas tecnologias no ensino médio. Horizontes, Dourados, v. 8, n. 15, p. 61-80, jan./jun. 2020.

SASSERON, Lúcia Helena. Ensino de ciências por investigação e o desenvolvimento de práticas: uma mirada para a Base Nacional Comum Curricular. RBPEC, Dourados, v. 18, n. 3, p. 1061-1085, dez. 2018.

SILVA, Michele Silveira da; GARCIA, Rosane Nunes. Base Nacional Comum curricular: uma análise sobre a temática saúde. Revista Electrónica de Enseñanza de las Ciencias, v. 19, n. 2, p. 320-345, 2020.

SIPAVICIUS, Bruno Kestutis de Alvarenga; SESSA, Patrícia da Silva. A Base Nacional Comum Curricular e a área de ciências da natureza: tecendo relações críticas. Atas de Ciências da Saúde, São Paulo, v. 7, p. 3-16, jan./dez. 2019.

SOUSA, Marta Caires de; GUIMARÃES, Ana Paula Miranda; AMANTES, Amanda. A saúde nos documentos curriculares oficiais para o ensino de ciências: da Lei de diretrizes e bases da educação à Base Nacional Comum Curricular. Revista Brasileira de Pesquisa em Educação em Ciências, Belo Horizonte, 19, p. 129-153, 2019.

VICENTE, Luciane da Silva. O currículo de ciências na Base Nacional Comum Curricular. Cadernos de Pósgraduação, São Paulo, v. 18, n. 2, p. 4-10, jul./dez. 2019.

\section{CIÊNCIAS - Teses e Dissertações \\ Total: 2}

COSTA, Philippe Nascimento da. Os conceitos de ciências e as reformas do ensino médio. 2019. Dissertação (Mestrado em Ensino de Ciências e Matemática) - Universidade Federal do Amazonas, Manaus, 2019.

GODOY, Bruno Silva. Demandas curriculares em inscrições textuais da comunidade disciplinar de Ensino de Biologia: o caso da BNCC. 2019. Dissertação (Mestrado em Educação) - Universidade do Estado do Rio de Janeiro, Rio de Janeiro, 2019.

Fonte: Dados da pesquisa organizados pelo autor.

Quadro 6 - Trabalhos sobre BNCC vinculados à categoria Educação Física

\section{EDUCAÇÃO FÍSICA - Artigos \\ Total: 27}

ABREU, Jerlane Santos. A Base Nacional Comum Curricular e a educação do corpo. Poíesis Pedagógica, Catalão, v. 17, p. 164-177, 2019.

ARROYO, Miguel. Corpos resistentes produtores de culturas corporais. haverá lugar na Base Nacional Comum?

Motrivivência, Florianópolis, v. 28, n. 48, p. 15-31, 2016.

Revista de Estudios Teóricos y Epistemológicos en Política Educativa, v. 6, e2118101, p. 1-38, 2021 Disponible en: <https://www.revistas2.uepg.br/index.php/retepe> 
BORDINHÃO, Lidiane Soares et al. Praxiologia motriz e as dimensões de conhecimento da BNCC: primeiras aproximações. Conexões: Educação Física, Esporte e Saúde, Campinas, v. 18, p. 1-12, 2020.

BOSCATTO, Juliano Daniel; IMPOLCETTO, Fernanda Moreto Impolcetto; DARIDO, Suraya Cristina. A Base Nacional Comum Curricular: uma proposição necessária para a Educação Física? Motrivivência, Florianópolis, v. 28, n. 48, p. 96-112, 2016.

CRUZ, Lauro Rafael; NEGRÃO, Alice Raquel Maia; ABREU, Meriane Conceição Paiva. Concepções e perspectivas à Educação Física na Base Nacional Comum Curricular do ensino médio no Brasil. Motrivivência, Florianópolis, v. 32, n. 62, p. 1-17, abr./jun. 2020.

DESSBESELL, Giliane; FRAGA, Alex Branco. Exercícios físicos na Base Nacional Comum Curricular: um estranho no nicho da cultura corporal de movimento. Movimento, Porto Alegre, v. 26, p. 1-14, 2020.

FOGANHOLI, Cláudia. O contexto da BNCC: reflexões sobre a diversidade na educação física escolar. Temas em Educação Física Escolar, Rio de Janeiro, v. 4, n. 2, p. 5-19, ago./dez. 2019.

FURTADO, Renan Santos; COSTA, Gustavo Henquire Oliveira. Perspectiva docente sobre as "repercussões" da Base Nacional Comum Curricular na formação de professores de Educação Física. Revista Cocar, Belém, v. 14, n. 28, p. 681-701, jan./abr. 2020.

INÁCIO, Humberto Luís de Deus et al. Práticas corporais de aventura na escola: possibilidades e desafios reflexões para além da Base Nacional Comum Curricular. Motrivivência, Florianópolis, v. 28, n. 48, p. 168-187, 2016.

MARTINELI, Telma Adriana Pacífico et al. A Educação Física na BNCC: concepções e fundamentos políticos e pedagógicos. Motrivivência, Florianópolis, v. 28, n. 48, p. 76-95, 2016.

MARTINELI, Telma Adriana Pacífico; VASCONCELOS, Carolina de Moura; ALMEIDA Eliane Maria de. Concepção pedagógica e curricular para o esporte na Base Nacional Comum Curricular. Revista Trama, Marechal Cândido Rondon, v. 14, n. 33, p. 106-117, 2018,

MELLO, André da Silva et al. A educação infantil na Base Nacional Comum Curricular: pressupostos e interfaces com a Educação Física. Motrivivência, Florianópolis, v. 28, n. 48, p. 130-149, 2016.

MOREIRA, Laine Rocha et al. Apreciação da Base Nacional Comum Curricular e a Educação Física em foco. Motrivivência, Florianópolis, v. 28, n. 48, p. 61-75, 2016.

NEIRA, Marcos Garcia. Incoerências e inconsistências da BNCC de Educação Física. Revista Brasileira de Ciências do Esporte, Brasília, v. 40, n. 3, p. 215-223, 2018.

NOVAES, Renato Cavalcanti; TRIANI, Felipe da Silva; TELLES, Silvio de Cássio Costa. A Educação Física na Base Nacional Comum Curricular: desconstruindo o discurso neoliberal. Revista Humanidades e Inovação, Palmas, v. 7, n. 10, p. 70-84, 2020.

PERTUZATTI, Ieda; DICKMANN, Ivo. Uma visão panorâmica da LDB à BNCC: as políticas públicas de alfabetização, letramento e suas relações com a cultura corporal na Educação Física. Motrivivência, Florianópolis, v. 28, n. 48, p. 113-129, 2016.

RODRIGUES, Anegleyce Teodoro. Base Nacional Comum Curricular. A área de linguagem e o componente curricular Educação Física. Motrivivência, Florianópolis, v. 28, n. 48, p. 32-41, 2016.

RODRIGUES, Rogério. A formação escolar e o componente curricular: a Educação Física em tempos de capitalismo mundial integrado. Ensino Em Re-Vista, Uberlândia, v. 25, n. 1, p. 216-233, jan./abr. 2018.

RUFINO, Luiz Gustavo Bonatto; SOUZA NETO, Samuel de. Saberes docentes e formação de professores de Educação Física: análise da Base Nacional Comum Curricular (BNCC) na perspectiva da profissionalização do ensino. Motrivivência, Florianópolis, v. 28, n. 48, p. 42-60, 2016.

SANTOS, Barbara Cristina Aparecida dos; FUZII, Fábio Tomio. A Educação Física na Área da Linguagem: o impacto da BNCC no currículo escolar. Comunicações, São Paulo, v. 26, n. 1, p. 327-347, jan./abr. 2019.

SANTOS, Marcio Antonio Raiol dos; BRANDÃO, Pedro Paulo Souza. Base Nacional Comum Curricular e Currículo da Educação Física: qual o lugar da diversidade cultural? Horizontes, Dourados, v. 36, n. 1, p. 105-118, jan./abr. 2018.

SENA, Dianne Cristina Souza de et al. A BNCC em discussão na formação continuada de professores de Educação Física: um relato de experiência - Natal/RN. Motrivivência, Florianópolis, v. 28, n. 49, p. 227-241, 2016.

SEVERINO, Antonio Joaquim; WUO PEREIRA, Dimitri; SANTOS, Vinícius Sampaio Feitoza dos. Aventura e educação na Base Nacional Comum. EccoS Revista Científica, São Paulo, n. 41, p. 107-125, set./dez. 2016.

SILVA, Adiel Oliveira da et al. Validação de itens para avaliação do conhecimento de atividade física para Educação Física no ensino fundamental. Research, Society and Development, Itajaí, v. 8, n. 7, p. 1-16, 2019.

SOARES, Marta Genú; ABREU, Meriane Conceição Paiva; TEIXEIRA, Carla Loyana Dias. A reforma do Ensino Médio - 2017: notas sobre a Formação de Professores, a Educação e a Educação Física. Ensino Em Re-Vista, Uberlândia, v. 25, n. 2, p. 452-473, maio/ago. 2018.

SOUZA, Adriano Lopes de et al. A Base Nacional Comum Curricular e seus desdobramentos para a Educação Física. Motrivivência, Florianópolis, v. 31, n. 59, p. 1-17, jul./set. 2019. 
A produção de conhecimento sobre a Base Nacional Comum Curricular no Brasil: levantamento...

TAVARES, Raquel Nunes; GARCIA, Lênin Tomazett; RODRIGUES, Anegleyce Teodoro. Base Nacional Comum Curricular e Educação Física: análise de tendências e lacunas da produção acadêmica no Brasil. Movimento - Revista de Educação, Niterói, ano 6, n.11, p. 185-207, jul./dez. 2019.

\section{EDUCAÇÃO FÍSICA - Teses e Dissertações \\ Total: 9}

ALMEIDA, Deberson Ferreira de. Base Nacional Comum Curricular: concepção do componente Educação Física para o Ensino Fundamental. 2018. Dissertação (Mestrado em Educação: Currículo) - Pontifícia Universidade Católica de São Paulo, São Paulo, 2018.

CAZUMBÁ, Elson Correia. Fundamentos teóricos metodológicos da Educação Física Presentes na BNCC do Ensino Médio. 2018. Dissertação (Mestrado em Educação) - Universidade Estadual de Feira de Santana, Feira de Santana, 2018.

DESTRO, Denise de Souza. Disputas políticas pela Educação Física escolar na Base Nacional Comum Curricular. 2019. Tese (Doutorado em Educação) - Universidade do Estado do Rio de Janeiro, Rio de Janeiro, 2019.

FONSECA, Carlos Alberto. O lazer na Base Nacional Comum Curricular (BNCC): uma análise documental. 2018. Dissertação (Mestrado em Estudos do Lazer) - Universidade Federal de Minas Gerais, Belo Horizonte, 2019.

LIMA, Claube Camile Soares. Jogo, infância e Educação Física: conhecimento e especificidade. 2018. Dissertação (Mestrado em Educação Física Escolar) -Universidade Federal de Santa Maria, Santa Maria, 2018.

LUZ, Júlio César Oliveira. O tema Saúde na Educação Física Escolar: tecitura histórica e proposições curriculares atuais. 2020. Dissertação (Mestrado em Educação Física) - Universidade de Brasília, Brasília, 2020.

PESSOA, Felipe de Marco. A Educação Física na construção da Base Nacional Comum Curricular (BNCC): avanços, limites e implicações políticas e pedagógicas. 2018. Dissertação (Mestrado em Educação) - Universidade Federal de Santa Catarina, Florianópolis, 2018.

PINHEIRO, Ellen Grace. A Educação Física Escolar na Base Nacional Comum Curricular: dinâmicas de um movimento em construção. 2018. Dissertação (Mestrado em Educação Física) - Universidade Estadual de Maringá, Maringá, 2018.

TAHARA, Alexander Klein. Práticas corporais de aventura: construção coletiva de um material didático digital. 2017. Tese (Doutorado em Desenvolvimento Humano e Tecnologias). - Universidade Estadual Paulista Júlio de Mesquita Filho, Rio Claro, 2017.

Fonte: Dados da pesquisa organizados pelo autor.

Quadro 7 - Trabalhos sobre BNCC vinculados à categoria Educação Infantil

\section{EDUCAÇÃO INFANTIL - Artigos}

Total: 27

ARIOSI, Cinthia Magda Fernandes. A Base Nacional Comum Curricular para educação infantil e os campos de experiência: reflexões conceituais entre Brasil e Itália. Revista Humanidades e Inovação, Palmas, v. 6, n. 15, p. 243-256, 2019.

BARBOSA, Maria Carmen Silveira et al. O que é básico na Base Nacional Comum Curricular para a Educação Infantil? Debates em Educação, Maceió, v. 8, n. 16, p. 11-28, jul./dez. 2016.

BASSOTTO, Bárbara de Almeida; BECKER, Elsbeth Léia Spode. Inteligências múltiplas relacionadas aos campos de experiência da Base Nacional Comum Curricular na Educação Infantil. Research, Society and Development, Itajaí, v. 9, n. 6, p. 1-21, 2020.

BIGOLIN, Danusa Aparecida; SILVA, Maria Terezinha Vieira da; CORÁ, Elsio José. O currículo da Educação Infantil no (com)texto da Base Nacional Comum Curricular. REFFEN, Natal, v. 1, n. 1, p. 68-83, 2020.

BORTOLANZA, Ana Maria Esteves; FREIRE, Renata Teixeira Junqueira. Educação Infantil e a Base Nacional Comum Curricular: concepções de criança, desenvolvimento e currículo. Série-Estudos, Campo Grande, v. 23, n. 49, p. 67-96, set./dez. 2018.

BUSS-SIMÃO, Marcia. Experiências sensoriais, expressivas, corporais e de movimentos nos campos de experiências da Base Nacional Comum Curricular para Educação Infantil. Debates em Educação, Maceió, v. 8, n. 16, p. 184-207, jul./dez. 2016.

CAMPOS, Rosânia; BARBOSA, Maria Carmen Silveira. BNC e Educação Infantil quais as possibilidades? Revista Retratos da Escola, Brasília, v. 9, n. 17, p. 353-366, jul./dez. 2015.

CEZARI, Eduardo; SOUZA, Jil-vanny da Silva Cunha; CUNHA, Rogério de Sousa. A Educação Infantil na Base Nacional Comum Curricular: conceitos e propostas de um currículo. Revista Observatório, Palmas, v. 2, n. especial 2, p. 456-475, out. 2016.

Revista de Estudios Teóricos y Epistemológicos en Política Educativa, v. 6, e2118101, p. 1-38, 2021 Disponible en: <https://www.revistas2.uepg.br/index.php/retepe> 
COSTA, Sinara Almeida da; TAPAJÓS, Jéssica Alves; SANTOS, Célia Maria Guimarães. Aprendizagem da criança: relação entre a BNCC e a teoria histórico-cultural. Educação em Revista, Marília, v. 21, n. 2, p. 9-20, 2020.

CUNHA, Myrtes Dias da; SILVA, Cecilia Rezende. Reflexões acerca da estrutura curricular para a Educação Infantil. Ensino Em Re-Vista, Uberlândia, v. 26, n. 1, p. 223-243, jan./abr. 2019.

DELMONDES, Marina de Oliveira; SILVA, Tamili Mardegan da. Os "Campos de Experiências" na Base Nacional Comum Curricular: do positivismo às invenções cotidianas. Linguagens, Educação e Sociedade, Teresina, ano 23, n. 38, p. 72-98, jan./jul. 2018.

FEITOSA, Soraya de Araújo; BARROS, Laura Juliana Neris Machado; FEITOZA, Sãmella Kalyne Araújo. Uma experiência sobre rotina escolar e planejamento didático na Educação Infantil na Amazônia. Horizontes, Dourados, v. 7, n. 14, p. 123-136, 2019.

GOMERS, Larissa Ferreira Rodrigues; ZOUAIN, Ana Cláudia Santiago; NUNES, Kezia Rodrigues. Se não se sabe de antemão como alguém vai aprender, como avaliar na Educação Infantil? Espaço do Currículo (online), João Pessoa, v. 12, n. 2, p. 339-351, maio/ago. 2019.

MELLO, Ana Paula Barbieri de; SUDBRACK, Edite Maria; PACHECO, Luci Mary Duso. Consciência fonológicas e Base Nacional Comum Curricular: mapeamento e discussão da produção acadêmica nos anos de 2006 - 2016. Cadernos de Pesquisa: Pensamento educacional, Curitiba, v. 14, n. 37, p. 98-118, maio/ago. 2019.

MONTEIRO, Cíntia Castro; CASTRO, Letícia de Oliveira; HERNECK, Heloisa Raimunda. O silenciamento da Educação Infantil: proposta da Base Nacional Comum Curricular (BNCC). Pedagogia em Ação, Belo Horizonte, v. 10, n. 1, p. 194-212, 2018.

MORAIS, Artur Gomes de; SILVA, Alexsandro da; NASCIMENTO, Gabryella Silva do. Ensino da notação alfabética e práticas de leitura e escrita na Educação Infantil: uma análise das três versões da Base Nacional Comum Curricular. Revista Brasileira de Educação, Rio de Janeiro, v. 25, p. 1-25, 2020.

PASQUALINI, Juliana Campregher; MARTINS, Lígia Márcia. Currículo por campos de experiência na Educação Infantil: ainda é possível preservar o ensino desenvolvente? RPGE- Revista on line de Política e Gestão Educacional, Araraquara, v. 24, n. 2, p. 425-447, maio/ago. 2020.

PEREIRA, Fabio Hoffmann. Campos de experiência e a BNCC: um olhar crítico. Zero-a-seis, Florianópolis, v. 22, n. 41, p. 73-89, 2020.

PORTELINHA, Ângela Maria Silveira et al. A Educação Infantil no contexto das discussões da Base Nacional Comum Curricular. Temas \& Matizes, Cascavel, v. 11, n. 20, p. 30-43, jan./jun. 2017.

SANTIAGO, Daniela Emilena; GOMES, Fernanda Gonçalves; SOUZA, Flávia Danieli. Base Nacional Curricular Comum (BNCC) para a Educação Infantil: um estudo a partir das metodologias de ensino. Revista Caminhando, v. 25 , n. 1, p. 185-198, jan./abr. 2020

SILVA, Ana Cleide da; COUTINHO, Diogenes José Gusmão. Educação infantil: a multiculturalidade na organização curricular com os campos de experiencias da Base Nacional Comum Curricular (BNCC). Brazilian Journal of Development, São José dos Pinhais, v. 5, n. 12, p. 28563-28581, dez. 2019.

SILVA, Ana Cleide da; COUTINHO, Diógenes José Gusmão. Educação Infantil: a organização curricular e a metodologia sugerida como os campos de experiências da Base Nacional Comum Curricular. Revista Ibero-

Americana de Humanidades, Ciências e Educação, São Paulo, v. 6, n. 2, p. 29-51, 2020.

SILVA, José Rogério da. Educação Infantil: da constituição de 1988 à BNCC, avanços e entraves. Educere, Cascavel, v. 20, n. 2, p. 371-392, jul./dez. 2020.

SILVA, Mellina; GUEDES-PINTO, Ana Lúcia. A leitura para a Educação Infantil na BNCC: continuidades e rupturas. Linha Mestra, Campinas, n. 40, p. 48-58, 2020.

SOUZA, Daiane Lanes de; SARTURI, Rosane Carneiro. Base Nacional Comum Curricular e processos de atuações na Educação Infantil. Textura, Canoas, v. 22 n. 50, p. 202-220, abr./jun. 2020.

TIRIBA, Léa; FLORES, Maria Luiza Rodrigues. A Educação Infantil no contexto da Base Nacional Comum Curricular: em defesa das crianças como seres da natureza, herdeiras das tradições culturais brasileiras. Debates em Educação, Maceió, v. 8, n. 16, p. 157-183, jul./dez. 2016.

VITTA, Fabiana Cristina Frigieri de; CRUZ, Girlene de Albuquerque; SCARLASSARA, Bárbara Solana. A Base Nacional Comum Curricular e o berçário. Horizontes, Dourados, v. 36, n. 1, p. 64-73, jan./abr. 2018.

\section{EDUCAÇÃO INFANTIL - Teses e Dissertações}

Total: 3

ALMEIDA, Vanessa da Silva. Base Nacional Comum Curricular: o que diz sobre modos de ser criança na educação infantil? 2019. Dissertação (Mestrado em Educação) - Universidade Luterana do Brasil, Canoas, 2019.

MELLO, Ana Paula Barbieri de. Políticas para a Educação Infantil: o lugar da consciência fonológica na Base Nacional Comum Curricular. 2018. Dissertação (Mestrado em Educação) - Universidade Regional Integrada do Alto Uruguai e das Missões, Frederico Westphalen, 2018. 
A produção de conhecimento sobre a Base Nacional Comum Curricular no Brasil: levantamento...

SOUZA, Daiane Lanes de. Base Nacional Comum Curricular e produção de sentidos de Educação Infantil: entre contextos, disputas e esquecimentos. 2019. Dissertação (Mestrado em Educação) - Universidade Federal de Santa Maria, Santa Maria, 2019.

Fonte: Dados da pesquisa organizados pelo autor.

Quadro 8 - Trabalhos sobre BNCC vinculados à categoria História

\section{HISTÓRIA - Artigos \\ Total: 22}

ALVES, Vânia Maria Siqueira. História na Base Nacional Comum Curricular do Ensino Médio: alguns apontamentos. Escritas, Palmas, v. 11, n. 1, p. 99-115, 2019.

FRANCO, Aléxia Pádua; SILVA JUNIOR, Astrogildo Fernandes da. GUIMARÃES, Selva. Saberes históricos prescritos na BNCC para o Ensino Fundamental: tensões e concessões. Ensino Em Re-Vista, Uberlândia, v. 25, n. especial, p. 1016-1035, 2018.

GOMES NETO, João Maurício. Tradição disciplinar e o desafio de construir currículos: recepções à BNCC para o componente de história. Saeculum - Revista de História, João Pessoa, n. 40, p. 351-376, 2019.

LIMA, Douglas Mota Xavier de. Uma história contestada: a História Medieval na Base Nacional Comum Curricular (2015-2017). Anos 90, Porto Alegre, v. 26, p. 1-21, 2019.

LIMA, Jonata Souza de; MUNIZ, Érico Silva. História da Amazônia, História do Brasil? uma análise sobre os conteúdos regionais na BNCC. Textura, Canoas, v. 22 n. 50, p. 265-288, abr./jun. 2020.

MACHADO, Juliana Porto; COLVERO, Ronaldo Bernardino; PORTO, Letícia Ferreira. Os reveses do Ensino de História Antiga no Brasil. RELACult - Revista Latino-Americana de Estudos em Cultura e Sociedade, Foz do Iguaçu, v. 5, n. especial, p. 1-11, abr. 2019.

MENESES NETO, Geraldo Magella de. As discussões sobre a Base Nacional Comum Curricular de História: entre polêmicas e exclusões (2015-2016). Crítica Histórica, Maceió, Ano VIII, n. 15, p. 31-61, jul. 2017.

MORENO, Jean Carlos. História na Base Nacional Comum Curricular: déjà vu e novos dilemas no século XXI. História \& Ensino, Londrina, v. 22, n. 1, p. 7-27, jan./jun. 2016.

OLIVEIRA, Dennison de. Uso de Periódicos para o Ensino de História na Educação Básica - Projeto 1.917: mídia, guerra, greve e revolução. Revista Intersaberes, Curitiba, v. 12, n. 25, p. 98-105, 2017,

PACINI, Henrique Ferreira. Lobo em pele de cordeiro: novas roupagens e velhas atitudes no ensino de história proposta pela BNCC. História \& Ensino, Londrina, v. 23, n. 1, p. 113-138, jan./jun. 2017.

PAZIANI, Rodrigo Ribeiro. A quem serve a Base Nacional Comum Curricular? dos apontamentos críticos na área de ciências humanas à análise específica do curso de histórica (UNIOESTE). Temas \& Matizes, Cascavel, v. 11, n. 20, p. 44-65, jan./jun. 2017.

PEREIRA, Nilton Mullet; RODRIGUES, Mara Cristina de Matos. BNCC e o passado prático: temporalidades e produção de identidades no ensino de história. Arquivos Analíticos de Políticas Educativas, Porto Alegre, v. 26, n. 107, p. 1-22, 2018.

PINTO, Jorge Vieira Eschriqui Vieira. reflexões acerca dos conceitos de Identidade e Diversidade na BNCC de História. História e Cultura, Franca, v. 8, n. 2, p. 335-352, ago./nov. 2019.

SANTOS, Dominique. o ensino de História Antiga no Brasil e o debate da BNCC. Outros Tempos, São Luís, v. 16, n. 28, p. 128-145, 2019.

SANTOS, Maria Aparecida Lima dos; RIBEIRO, Suzana Lopes Salgado; ONÓRIO, Wanessa Odorico. Ensino de História na Base Nacional Comum Curricular (BNCC): sentidos de diversidade nos anos iniciais. RPGE - Revista on line de Política e Gestão Educacional, Araraquara, v. 24, n. esp. 2, p. 961-978, set. 2020.

SILVA JÚNIOR, Astrogildo Fernandes da. BNCC, Componentes Curriculares de História: perspectivas de superação do eurocentrismo. EccoS Revista Científica, São Paulo, n. 41, p. 91-106, set./dez. 2016.

SILVA, Francisco José Balduino da; SANTOS, Jean Mac Cole Tavares; FERNANDES, Márcia Frota. BNCC e o Currículo de História: interpretações docentes no contexto da prática. Currículo sem Fronteiras, v. 19, n. 3 , p. 1011-1025, set./dez. 2019.

SILVA, Francisco Thiago; VASCONCELOS, Laryssa; CASAGRANDE, Robson Carlos. A Base Nacional Comum Curricular e o ensino de História: reflexões docentes. Projeção e Docência, Contagem, v. 7, n. 2, p. 1-14, 2016.

SILVA, Marco Antônio; MORAIS, Suelena Maria de. Atitude historiadora na leitura dos não Lugares. E-hum, Belo Horizonte, v. 10, n. 2, p. 114-128, jul./dez. 2017.

SILVA, Marcos. "Tudo que você Consegue Ser" - triste BNCC/História (a versão final). Ensino Em Re-Vista, Uberlândia, v. 25, p. 1004-1015, 2018.

TAMANINI, Paulo Augusto; NORONHA, Vanusa Maria Gomes. O ensino de História e a BNCC: livros didáticos sob uma análise comparativa. Teias, Rio de Janeiro, v. 20, n. 57, p. 109-124, abr./jun. 2019.

Revista de Estudios Teóricos y Epistemológicos en Política Educativa, v. 6, e2118101, p. 1-38, 2021 Disponible en: <https://www.revistas2.uepg.br/index.php/retepe> 
TEIXEIRA, Igor Salomão; PEREIRA, Nilton Mullet. A Idade Média nos Currículos escolares: as controvérsias nos debates sobre a BNCC. Diálogos, Maringá, v. 20, n. 3, p. 16-29, 2016.

\section{HISTÓRIA - Teses e Dissertações \\ Total: 5}

CATELAN, Magdale Machado. A influência das políticas neoliberais no Ensino de História nos anos finais do Ensino Fundamental. 2018. Dissertação (Mestrado em Ensino de Humanidades e Linguagens) - Universidade Franciscana, Santa Maria, 2018.

FELICIO, Silvio Celioi. Reforma do ensino médio e a disciplina História: leituras sobre as repercussões da proposta da BNCC. 2019. Dissertação (Mestrado Profissional em História) - Universidade Federal de Goiás, Catalão, 2019.

MACHADO, Vinicius Oliveira. Crítica ao esvaziamento do currículo de História: a BNCC e a pedagogia das competências. 2019. Dissertação (Mestrado em Educação) - Universidade Federal do Espírito Santo, Vitória, 2019. OLIVEIRA, Mariana Xavier de. Base Nacional Comum Curricular - BNCC: da política pública curricular ao ensino de História. 2018. Dissertação (Mestrado Profissional em História) - Universidade Federal de Rio Grande, Rio Grande, 2018.

PEREIRA, Acacia Regina. Percursos do ensino de História da África e dos Afro-brasileiros na $1^{\text {a }}$ versão do componente Curricular História da BNCC São Gonçalo 2018. 2018. Dissertação (Mestrado em História Social) - Universidade do Estado do Rio de Janeiro, São Gonçalo, 2018.

Fonte: Dados de pesquisa organizados pelo autor.

Quadro 9 - Trabalhos sobre BNCC vinculados à categoria Geografia

\section{GEOGRAFIA - Artigos}

Total: 18

ARAÚJO, Gilvan Charles Cerqueira de; KUNZ, Sidelmar Alves da Silva. A Base Nacional Comum Curricular (BNCC), o ensino de geografia e o papel do estado. Revista Tocantinense de Geografia, Palmas, v. 9, n. 19, p. 1-25, set./dez. 2020.

ARAÚJO, Gilvan Charles Cerqueira de; KUNZ, Sidelmar Alves da Silva. Geografia escolar e currículo: aportes da construção do saber geográfico e dos postulados acadêmicos. Revista Ensino de Geografia, Recife, v. 2, n. 2, p. 99-112, 2019.

ASCENÇÃO, Valéria de Oliveira Roque. A Base Nacional Comum Curricular e a produção de práticas para a geografia escolar: desdobramentos na formação docente. Revista Brasileira de Educação em Geografia, Campinas, v. 10, n. 19, p. 173-197, jan./jun. 2020.

COSTA, Hugo Heleno Camilo. Teoria curricular e Geografia: convites à reflexão sobre a BNCC. Revista Brasileira de Educação em Geografia, Campinas, v. 9, n. 17, p. 86-108, jan./jun. 2019.

COUTO, Marcos Antônio Campos. Base Nacional Comum Curricular - BNCC componente Curricular: Geografia. Revista da Associação Nacional de Pós-graduação e Pesquisa em Geografia (Anpege), Dourados, v. 12, n. 19, p.183-203, jul./dez. 2016.

CRUZ, Francisco Herbster Alencar et al. Análise crítico-compreensiva da Base Nacional Comum Curricular voltada para os conteúdos de Geografia Física na Educação Básica. Revista de Geociências do Nordeste - REGNE, Caicó, v. 2, n. especial, p. 1401-1410, 2016.

CUNHA, Leonardo Ferreira Farias da. A Geografia escolar e as temáticas físico-naturais na BNCC: desafios à prática docente e à formação de professores. Itinerarius Reflectionis, Jataí, v. 14, n. 2, p. 1-18, 2018.

DINIZ, Vanessa Lessio; MOURA, Osmar Oliveria de. Interlocuções sobre currículo e a implementação da BNCC de Geografia: buscando pedagogias decoloniais para o contexto amazônico. e-Curriculum, São Paulo, v. 18, n. 4, p. $1668-1690,2020$

FERRAZ, João Paulo; NASCIMENTO, Luciana de Abreu. A discussão de Geografia: proposições a partir dos componentes curriculares da Base Nacional Comum Curricular para os anos finais do Ensino Fundamental. Geographia Opportuno Tempore, Londrina, v. 5, n. 2, p. 85-103, 2019.

GIROTTO, Eduardo Donizeti. Dos PCNs a BNCC: o ensino de geografia sob o domínio neoliberal. Geo UERJ, Rio de Janeiro, n. 30, p. 419-439, 2017.

GUIMARÃES, Iara Vieira. Ensinar e aprender Geografia na Base Nacional Comum Curricular (BNCC). Ensino Em Re-Vista, Uberlândia, v. 25, n. especial, p. 1046-1055, 2018.

MESQUISTA, Adriel Leandro; ROSSETTO, Onélia Carmem; CANTÓIA, Sílvia Fernanda. A Geografia agrária na Base Nacional Comum Curricular (BNCC). Terra Livre São Paulo, São Paulo, ano 35, v. 1, n. 54, p. 886-922, 2020.

Revista de Estudios Teóricos y Epistemológicos en Política Educativa, v. 6, e2118101, p. 1-38, 2021 Disponible en: <https://www.revistas2.uepg.br/index.php/ retepe> 
A produção de conhecimento sobre a Base Nacional Comum Curricular no Brasil: levantamento...

NASCIMENTO, Diego Tarley Ferreira. Propostas de mapeamentos colaborativos como estratégias para o Ensino de Geografia. GEOSABERES: Revista de Estudos Geoeducacionais, Fortaleza, v. 10, n. 22, 2019.

PORTELA, Mugiany Oliveira Brito. A BNCC para o ensino de Geografia: a proposta das ciências humanas e da interdisciplinariedade. Revista OKARA: Geografia em debate, João Pessoa, v. 12, n. 1, p. 48-68, 2018.

SANTOS, Leovan Alves dos. Reflexões sobre o ensino de Geografia em Goiás a partir da introdução da Base Nacional Comum Curricular. Revista Educação e Políticas em Debate, Uberlândia, v. 8, n. 3, p. 467-480, set./dez. 2019.

SANTOS, Lidiane Rebouças. A disciplina de Geografia e o discurso competente na terceira versão da Base Nacional Comum Curricular. Revista Brasileira de Educação em Geografia, Campinas, v. 9, n. 18, p. 20-36, jul./dez. 2019.

SILVA, Alcinéia de Souza. Questões que perpassam o ensino de Geografia como as proposições da Base Nacional Comum Curricular. Revista Brasileira de Educação em Geografia, Campinas, v. 7, n. 13, p. 417-437, jan./jun. 2017.

VALLADARES, Marisa Terezinha Rosa et al. Contexto da construção da primeira e segunda versões da Base Nacional Comum Curricular no Componente Curricular de Geografia. Giramundo, Rio de Janeiro, v. 3, n. 6, p. 7 18, jul./dez. 2016

\section{GEOGRAFIA - Teses e Dissertações \\ Total: 3}

MUSTAFE, Diego Nascimento. O ensino de Geografia na BNCC do ensino fundamental (anos iniciais e anos finais): a escala geográfica e o conceito de lugar com vistas à formação cidadã do aluno. 2019. Dissertação (Mestrado em Geografia) - Universidade Federal de Goiás, Goiânia, 2019.

OZORIO, Augusto Monteiro. O ensino da Geografia e sua especificidade na Base Nacional Comum Curricular Brasileira: uma cartografia das ausências. 2018. Tese (Doutorado em Educação - Currículo) - Pontifícia Universidade Católica de São Paulo, São Paulo, 2018.

SIQUEIRA, Alan Souza Taylor de. Entre os PCNs e a BNCC: discursos sobre integração curricular na Geografia. 2019. Dissertação (Mestrado em Educação) - Universidade Federal do Rio de Janeiro, Rio de Janeiro, 2019.

Fonte: Dados da pesquisa organizados pelo autor.

Quadro 10 - Trabalhos sobre BNCC vinculados à categoria Arte

\section{ARTE - Artigos}

Total: 13

CAVALCANTE, Cláudia Garcia Cavalcante; SANTOS, José Luiz de Souza. Protagonismo teatral e protagonismo educacional: quais deslocamentos fazem surgir um a(u)tor? Bakhtiniana, São Paulo, v. 14, n. 3, p. 156-175, jul./set. 2019.

COUTINHO, Karyne Dias; ALVES, Jefferson Fernandes. As Artes na Base Nacional Comum Curricular. Textura, Canoas, v. 22, n. 50, p. 241-264, abr./jun. 2020

HENCKE, Jésica; SILVA, João Alberto da. Cartografia do Ensino de Artes no Brasil: das Belas Artes à BNCC. RELACult - Revista Latino-Americana de Estudos em Cultura, Foz do Iguaçu, v. 5, n. especial, p. 1-26, abr. 2019. IAVELBERG, Rosa. A Base Nacional Curricular Comum e a formação dos professores de Arte. Horizontes, Itatiba, v. 36, n. 1, p. 74-84, jan./abr. 2018.

MARQUES, Edite Colares Oliveira. Considerações sobre Educação, Arte e Política: experiências, alternativas e resistências. Conhecer: debate entre o público e o privado, Itaperi, v. 9, n. 23, p. 124-140, 2019.

MARTINS, Denise Andrade de Freitas; VILELA, Maria Aparecida Augusto Satto. A proposta da Base Nacional Comum Curricular para o ensino de Arte. Motricidades: Revista SPQMH, São Carlos, v. 3, n. 3, p. 177-187, set./dez. 2019.

PIMENTEL, Lucia Gouvêa; MAGALHÃES, Ana Del Tabor Vasconcelos. Docência em Arte no contexto da BNCC: é preciso reinventar o ensino/aprendizagem em Arte? Revista GEARTE, Porto Alegre, v. 5, n. 2, p. 220231, maio/ago. 2018.

SANTOS, Marta da Cunha; GHISLENI, Taís Steffenello. Impactos da Educomunicação na Educação Básica e a sua contribuição para a prática docente. Research, Society and Development, Itajaí, v. 8, n. 3, p. 1-21, 2019.

SANTOS, Micael Carvalho dos. A Educação Musical na Base Nacional Comum Curricular (BNCC) - Ensino Médio: teias da política educacional curricular pós-golpe 2016 no Brasil. Revista da Abem, Recife, v. 27, n. 42, p. 52-70, jan./jun. 2019

SARDELICH, Maria Emília; PANHO, Guilherme. Uma cartografia sobre o Ensino das Artes Visuais na BNCC entre 2014-2018. Revista GEARTE, Porto Alegre, v. 5, n. 2, p. 232-244, maio/ago. 2018. 
SOUZA, Bruna Costa Mariano Ferreguetti. Musicalização na Educação Infantil: um olhar sobre a Base Nacional Comum Curricular. Revista da FUNDARTE, Montenegro, ano 20, n. 40, p. 51-64, jan./mar. 2019.

TOLENTINO, Igor Vieira e Sá; MORENO, Alessandra Domeniquelli. Artes na BNCC: reflexões psicopedagógicas. Cadernos de Educação, São Paulo, v. 18, n. 37, p. 5-30, jul./dez. 2019.

VIEIRA, Marcilio de Souza. Interfaces entre a Dança, a Educação Infantil e a Base Nacional Comum Curricular (BNCC). PÓS: Revista do Programa de Pós-graduação em Artes da EBA/UFMG, Belo Horizonte, v. 8, n. 16, p. 8-25, nov. 2018.

\section{ARTE - Teses e Dissertações \\ Total: 1}

PANHO, Guilherme. As Artes Visuais para o Ensino Fundamental na Base Nacional Comum Curricular. 2019. Dissertação (Mestrado em Artes Visuais) - Universidade Federal de Pernambuco, João Pessoa, 2019.

Fonte: Dados da pesquisa organizados pelo autor.

Quadro 11 - Trabalhos sobre BNCC vinculados à categoria Ensino Religioso

\section{ENSINO RELIGIOSO - Artigos \\ Total: 12}

BAPTISTA, Mauro Rocha. O Ensino Religioso e a Nova Base Nacional Comum Curricular (BNCC). Religare, João Pessoa, v. 16, n. 1, p. 228-263, 2019.

CUNHA, Luiz Antônio. A entronização do Ensino Religioso na Base Nacional Curricular Comum. Educação \& Sociedade, Campinas, v. 37, n. 134, p. 266-284, jan./mar. 2016.

CUNHA, Luiz Antônio. Três décadas de conflitos em torno do Ensino Público; laico ou religioso? Educação \& Sociedade, Campinas, v. 39, n. 145, p. 890-907, out./dez. 2018.

FERREIRA, Renan da Costa; BRANDENBURG, Laude Erandi. O Ensino Religioso e a BNCC: possibilidades de se educa para a paz. Caminhos, Goiânia, v. 17, n. 2, p. 508-522, maio/ago. 2019.

FREITAS, Eliane Maura Littig Milhomem de. Base Nacional Comum Curricular do Ensino Religioso: primeiro passo para os percursos da aprendizagem dessa área do conhecimento. Revista Último Andar, São Paulo, n. 28, p. 43-58, 2016.

GONÇALVES, Rafael Marques; ALMEIDA, Talita Pereira de. A BNCC e o Ensino Religioso em tempos de relações de poder e interesses ocultos. Currículo sem Fronteiras, v. 19, n. 3, p. 963-974, set./dez. 2019.

JUNQUEIRA, Sérgio Rogério Azevedo; ITOZ, Sônia. Escola católica: Ensino Religioso e BNCC. Revista de Educação, Niterói, ano 42, n. 158, p. 12-27, jan./jun. 2019.

SANTOS, Ana Maria dos. Ensino Religioso: uma abordagem sobre a segunda versão da Base Nacional Comum Curricular. Revista Unitas, Vitória, v. 5, n. 2, (n. especial), p. 796-817, 2017.

SANTOS, Mirinalda Alves Rodrigues dos. O Ensino Religioso nas Políticas de Currículo: o caso da Base Nacional Comum Curricular. pragMATIZES - Revista Latino-Americana de Estudos em Cultura, Rio de Janeiro, ano 7, n. 13, p. 53-64, abr./set. 2017.

SANTOS, Mirinalda. Base Nacional Comum Curricular: desafios e implicações para o ensino religioso. Espaço do Currículo, João Pessoa, v. 8, n. 3, p. 293-305, set./dez. 2015.

SANTOS, Taciana Brasil dos. Apontamentos sobre o Ensino Religioso Escolar: uma contribuição da Pedagogia de Comênio. Interações, Belo Horizonte, v. 14, n. 25, p. 205-226, 2019.

SILVA, José Carlos da. O Currículo e o Ensino Religioso na BNCC: reflexões e perspectivas. Revista Pedagógica, Chapecó, v. 20, n. 44, p. 56-65, 2018.

\section{ENSINO RELIGIOSO - Teses e Dissertações \\ Total: 2}

ALBERTINI, Mariana de Lima. O Ensino Religioso em escolas particulares católicas de São Paulo: percepções sobre a BNCC. 2020. Dissertação (Mestrado em Ciência da Religião) - Pontifícia Universidade Católica de São Paulo, São Paulo, 2020.

FREITAS, Eliane Maura Littig Milhomem de. Bem-me-quer, Malmequer: um estudo sobre a presença do ensino religioso na Base Nacional Comum Curricular. 2018. Tese (Doutorado em Ciência da Religião) - Pontifícia Universidade Católica de São Paulo, São Paulo, 2018.

Fonte: Dados da pesquisa organizados pelo autor.

Revista de Estudios Teóricos y Epistemológicos en Política Educativa, v. 6, e2118101, p. 1-38, 2021 Disponible en: <https:/ /www.revistas2.uepg.br/index.php/ retepe> 
A produção de conhecimento sobre a Base Nacional Comum Curricular no Brasil: levantamento...

Quadro 12 - Trabalhos sobre BNCC vinculados à categoria Educação Ambiental

\section{EDUCAÇÃO AMBIENTAL - Artigos \\ Total: 12}

BARBOSA, Giovani de Souza; OLIVEIRA, Caroline Terra de. Educação Ambiental na Base Nacional Comum Curricular. Revista Eletrônica do Mestrado em Educação Ambiental, Rio Grande, v. 37, n. 1, p. 323-335, jan./abr. 2020.

BAUMGRATZ, Cleiton Edmundo et al. Educação Ambiental: sensibilização e reflexão ambiental por oficinas e rodas de conversa. Revista Brasileira do Ensino Médio, Ipojuca, v. 3, p. 4-17, 2020.

BEHREND, Danielle Monteiro; COUSIN, Cláudia da Silva; GALIAZZI, Maria do Carmo. Base Nacional Comum Curricular: o que se mostra de referência à educação ambiental? Ambiente \& Educação, Rio Grande, v. 23, n. 2, p. 74-89, 2018.

BRANCO, Emerson Pereira; ROYER, Marcia Regina; BRANCO, Alessandra Batista de Godoi. A abordagem da Educação Ambiental nos PCNs, nas DCNs e na BNCC. Nuances: estudos sobre Educação, Presidente Prudente, v. 29, n. 1, p.185-203, jan./abr. 2018.

COSTA, Ramon Fabricio da Silva; NASCIMENTO, Francinaide de Lima Silva; AZEVEDO, Pablo Guimarães. A Base Nacional Comum Curricular e a Educação Ambiental: avanços e retrocessos nas recomendações para o Ensino de Geografia na Educação Básica. Research, Society and Development, Itajaí, v. 9, n. 1, p. 1-16, 2020.

CREPALDI, Geise Daniele Milagres; BONOTTO, Dalva Maria Bianchini. Educação Ambiental: um direito da Educação Infantil. Revista Zero-a-seis, Florianópolis, v. 20, n. 38, p. 375-396, jul./dez. 2018.

FONSECA, Erique da Costa; SILVA, Yuri Breno da Silva e. Inovações na implantação da Base Nacional Comum Curricular: uma análise sobre o bioparque da Amazônia. Revista Brasileira de Educação Ambiental, São Paulo, v. 15 , n. 3, p. $217-228,2020$.

MARQUES, Ronualdo; RAIMUNDO, Jerry Adriano; XAVIER, Claudia Regina. Educação Ambiental: retrocessos e contradições na Base Nacional Comum Curricular. Interfaces da Educação, Paranaíba, v. 10, n. 28, p. 445-467, 2019.

OLIVEIRA, Lucas de; NEIMAN, Zysman. Educação Ambiental no âmbito escolar: análise do processo de elaboração e aprovação da Base Nacional Comum Curricular (BNCC). Revista Brasileira de Educação Ambiental, São Paulo, v. 15, n. 3, p. 36-52, 2020.

ROSENDO, Daniela; LAPA, Fernanda Brandão. Educação e (m) Direitos Humanos e BNCC: competências socioemocionais e ética ambiental. Espaço do Currículo (online), João Pessoa, v. 11, n. 3, p. 470-483, set./dez. 2018.

SANTINELO; Paulo Cesar Canato; ROYER, Marcia Regina; ZANATTA, Shalimar Calegari. A Educação Ambiental no contexto preliminar da Base Nacional Comum Curricular. Pedagogia em Foco, Iturama, v. 11, n. 6, p. 104-115, jul./dez. 2016.

SILVA, Silvana do Nascimento; LOUREIRO, Carlos Frederico Bernardo. As vozes de professores-pesquisadores do campo da Educação Ambiental sobre a Base Nacional Comum Curricular (BNCC): Educação Infantil ao Ensino Fundamental. Ciência \& Educação, Bauru, v. 26, p. 1-15, 2020.

\section{EDUCAÇÃO AMBIENTAL - Teses e Dissertações Total: 1}

OLIVEIRA, Lucas de. Educação Ambiental no âmbito escolar: análise do desenvolvimento da elaboração e aprovação da Base Nacional Comum Curricular (BNCC). 2019. Dissertação (Mestrado em Ensino de Ciências e Matemática) - Universidade Federal de São Paulo, Diadema, 2019.

Fonte: Dados da pesquisa organizados pelo autor.

Quadro 13 - Trabalhos sobre BNCC vinculados à categoria Alfabetização-Letramento

\section{ALFABETIZAÇÃO-LETRAMENTO - Artigos Total: 11}

ALMEIDA, Maria Leoneide Rodrigues de. O Letramento, os Multiletramentos e as Mediações metodológicas: três aspectos das aprendizagens de leitura no trilho da BNCC. Revista de Educação, Brasília, ano 42, n. 160, p. 11-31, out./dez. 2019.

ANDRADE, Francisco Rogiellyson da Silva; LIMA, Priscila Sandra Ramos de; GOMES, Dannytza Serra. Ensino de figuras de linguagem à luz dos estudos do letramento e das orientações da BNCC. Revista X, Curitiba, v. 15, n. 3, p. 201-219, 2020.

Revista de Estudios Teóricos y Epistemológicos en Política Educativa, v. 6, e2118101, p. 1-38, 2021 Disponible en: <https://www.revistas2.uepg.br/index.php/retepe> 
ARANDA, Maria Alice de Miranda; TRICHES, Eliane de Fátima. O processo alfabetizador da criança no movimento de (re)formulação da Base Nacional Comum Curricular (BNCC). DiversaPrática, Uberlândia, v. 5, n. 2, p. 155-213, 2018.

BORTOLANZA, Ana Maria Esteves; GOULART, Ilsa do Carmo Vieira; CABRAL, Giovanna Rodrigues. Diferentes perspectivas de alfabetização a partir da Base Nacional Comum Curricular: concepções e desafios.

Ensino em Re-Vista, Uberlândia, v. 25, n. especial, p. 958-983, 2018.

BRUM, Maísa Helena; FUZER, Cristiane. Representações de Letramento na BNCC para o Ensino Fundamental nos componentes Curriculares Língua Portuguesa e Língua Inglesa. Horizontes de Linguística Aplicada, Brasília, ano 18, n. 1, p. 161-184, 2019.

FRADE, Isabel Cristina Alves da Silva. Palavra Aberta - BNCC e a Alfabetização em duas versões: concepções e desafios. Educação em Revista, Belo Horizonte, v. 36, p. 1-15, 2020.

FREIRE, Renata Teixeira Junqueira; BORTOLANZA, Ana Maria Esteves. Sobre letrar ou alfabetizar na Educação Infantil: a linguagem na Base Nacional Comum Curricular. Revista Brasileira de Alfabetização - ABAlf, Vitória, v. 1, n. 4, p. 171-186, jul./dez. 2016.

GONTIJO, Cláudia Maria Mendes; COSTA, Dania Monteiro Vieira; PEROVANO, Nayara Santos. Alfabetização na Base Nacional Comum Curricular (BNCC). Pro-Posições, Campinas, v. 31, p. 1-21, 2020.

PERTUZATTI, Ieda; DICKMANN, Ivo. Alfabetização e letramento nas políticas públicas: convergências e divergências com a Base Nacional Comum Curricular (BNCC). Ensaio: avaliação e Políticas Públicas em Educação, Rio de Janeiro, v. 27, n. 105, p. 777-795, out./dez. 2019.

STOCKMANNS, Jussara Isabel; FONSECA, Natália Ribas. Alfabetização e aprendizagem: uma reflexão sobre a Base Nacional Comum Curricular. Notandum, Maringá, ano XXII, n. 50, p. 85-102, maio/ago. 2019.

TEIXEIRA, Zildiane Souza; MARTINS, Kézia Siméia Barbosa da Silva. Base Nacional Comum Curricular (BNCC) e o processo de alfabetização e letramento da criança: impactos para a escola de ensino fundamental em Parintins, AM. Brazilian Journal of Development, Curitiba, v. 6, n. 6, p. 37591-37603, jun. 2020.

\section{ALFABETIZAÇÃO-LETRAMENTO - Teses e Dissertações Total: 2}

PERTUZATTI, IEDA. Alfabetização e letramento nas Políticas Públicas: convergências e divergências com a BNCC. 2017. Dissertação (Mestrado em Educação) - Universidade Comunitária da Região de Chapecó, Chapecó, 2017.

TRICHES, Eliane de Fátima. A formulação da Base Nacional Comum Curricular (BNCC) e concepções em disputa sobre o processo alfabetizador da criança (2015-2017). 2018. Dissertação (Mestrado em Educação) Universidade Federal da Grande Dourados, Dourados, 2018.

Fonte: Dados da pesquisa organizados pelo autor.

Quadro 14 - Trabalhos sobre BNCC vinculados à categoria Gênero e Sexualidade

\section{GÊNERO E SEXUALIDADE - Artigos \\ Total: 11}

ALVES, Eliane Fernandes Gadelha; SALUSTIANO, Dorivaldo Alves. Concepções de diversidade na Base Nacional Comum Curricular - BNCC. Interritórios - Revista de Educação Universidade Federal de Pernambuco, Recife, v. 6, n. 11, p. 100-123, 2020.

BESSA-OLIVEIRA, Marcos Antônio; ORTIZ, Marcela dos Santos. BNCC - caminhos e (im)possibilidades para gênero: por que a educação escanteou as mulheres e seus corpos? Educação em Revista, Marília, v. 21, n. especial, p. 73-88, 2020.

EVANGELISTA, Anderson Pereira; GONÇALVES, Rafael Marques. Gênero e diversidade sexual na Base Nacional Comum Curricular: descritores ausentes que tornam abjetos os corpos transgressores da norma. Revista Exitus, Santarém, v. 10, p. 1-26, 2020.

FERREIRA, Windyz Brazão. O conceito de diversidade na BNCC Relações de poder e interesses ocultos. Retratos da Escola, Brasília, v. 9, n. 17, p. 299-319, jul./dez. 2015.

FREIRE, Priscila. Ideologia de gênero e a política de educação no Brasil: exclusão e manipulação de um discurso heteronormativo. Exæquo, Lisboa, n. 37, p. 33-46, 2018.

GIOVANNETTI, Carolina; SALES, Shirlei Rezende. Histórias das mulheres na BNCC do Ensino Médio: o silêncio que persiste. Revista Eletrônica História em Reflexão - REHR, Dourados, v. 14, n. 27, p. 251-277, jan./jun. 2020.

MENEZES, Flávia Maria de; MONSORES, Luciana Helena. Educação Infantil e gêneros nas narrativas da BNCC. Revista Veras, São Paulo, v. 7, n. 2, p. 285-297, jul./dez. 2017.

Revista de Estudios Teóricos y Epistemológicos en Política Educativa, v. 6, e2118101, p. 1-38, 2021 Disponible en: < https://www.revistas2.uepg.br/index.php/ retepe> 
A produção de conhecimento sobre a Base Nacional Comum Curricular no Brasil: levantamento...

MONTEIRO, Solange Aparecida de Souza; RIBEIRO, Paulo Rennes Marçal. Sexualidade e gênero na atual BNCC: possibilidades e limites. Pesquisa e Ensino, Barreiras, v. 1, p. 1-24, 2020.

NASCIMENTO, Maria Lívia; CHIARADIA, Cristiana de França. A retirada da orientação sexual do Currículo Escolar: regulações da vida. Sisyphus Jornal of Education, Lisboa, v. 5, n. 1, p. 101-116, 2017.

SILVA, Caio Samuel Franciscati da; BRANCALEONI, Ana Paula Leivar; OLIVEIRA, Rosemary Rodrigues de. Base Nacional Comum Curricular e diversidade sexual e de gênero: (des)caracterizações. RIAEE - Revista IberoAmericana de Estudos em Educação, Araraquara, v. 14, n. esp. 2, p. 1538-1555, jul. 2019.

SOUZA JUNIOR, Paulo Roberto. A questão de gênero, sexualidade e orientação sexual na atual Base Nacional Comum Curricular (BNCC) e o movimento LGBTTQIS. Revista de Gênero, Sexualidade e Direito, Florianópolis, v. 4, n. 1, p. 1-21, jan./jun. 2018.

\section{GÊNERO E SEXUALIDADE - Teses e Dissertações}

Total: 2

ALVES, Eliane Fernandes Gadelha. Concepções de diversidade na Base Nacional Comum Curricular - anos iniciais do ensino fundamental. 2019. Dissertação (Mestrado em Educação) - Universidade Federal de Campina Grande, Campina Grande, 2019.

MAIA, Marilia Milhomem Moscoso. Gênero no contexto escolar da Educação Infantil: produções institucionais (RCNEI e BNCC) São Luís. 2017. Dissertação (Mestrado em Cultura e Sociedade) - Universidade Federal do Maranhão, São Luís, 2017.

Fonte: Dados da pesquisa organizados pelo autor.

Quadro 15 - Trabalhos sobre BNCC vinculados à categoria Língua Inglesa

\section{LÍNGUA INGLESA - Artigos \\ Total: 12}

FARIAS, Priscila Fabiane; SILVA, Leonardo da. "I'm Gonna Leave you with the Backlash Blues": uma análise acerca da concepção do ensino de língua inglesa na Base Nacional Comum Curricular sob o viés da Pedagogia Crítica. e-Curriculum, São Paulo, v. 18, n. 1, p. 137-157, jan./mar. 2020.

FISTAROL, Caique Fernando da Silva; FISCHER, Adriana; WENDERLICH, Rosana Clarice Coelho. A Base Nacional Comum Curricular e a formação de professores de Língua Inglesa: desafios e possibilidades. RPGERevista on line de Política e Gestão Educacional, Araraquara, v. 23, n. 2, p. 341-355, maio/ago. 2019.

LIMA, Ana Paula de; BORGHI, Raquel Fontes; SOUZA NETO, Samuel de. Base Nacional Comum Curricular e a lacuna no ensino de Inglês para crianças no Brasil. Cadernos de Pesquisa, São Luís, v. 26, n. 1, p. 9-29, jan./mar. 2019.

LINS JR., José Raymundo. Políticas Linguísticas: entre a construção da BNCC e a obrigatoriedade do inglês no ensino médio. Conexões Ciência e Tecnologia, Fortaleza, v. 12, n. 2, p. 63-73, nov. 2018.

LUCENA, Maria Inêz Probst; TORRES, Ana Cecília da Gama. Ideologia monolíngue, mercantilização e instrumentalização da Língua Inglesa na alteração da LDB em 2017 e em anúncios publicitários de cursos livres.

Revista Brasileira de Linguística Aplicada, Belo Horizonte, v. 19, n. 3, p. 635-654, 2019.

MELLO, Etiene Caroline Farias de; BOSCARIOLI, Clodis. Recursos educacionais abertos nas aulas de Língua Inglesa: criação de atividades alinhadas à Base Nacional Comum Curricular. Polyphonía, Goiânia, v. 30, n. 1, p. 120-132, jan./jun. 2019.

RAMOS, Kesley Vieira; ALVARENGA, Marcia Soares de. O ensino do Inglês na Base Nacional Comum Curricular: embates entre língua Franca e língua de fronteira. Humanidades e Inovação, Palmas, v. 7, n. 3, p. 334$347,2020$.

RIBAS, Fernanda Costa. Base Nacional Comum Curricular e o ensino de Língua Inglesa: refletindo sobre cidadania, diversidade e criticidade à luz do Letramento Crítico. Domínios de Lingu@gem, Uberlândia, v. 12, n. 3, p. 17841824, jul./set. 2018.

SILVA, Leandro Santos; LADEIA, Sheila Rocha; CRUZ, Giêdra Ferreira. Interculturalidade, ensino de Inglês como língua franca e a Base Nacional Comum Curricular. Fólio - Revista de Letras, Vitória da Conquista, v. 10, n. 1, p. 599-616, jan./jun. 2018.

SILVA, Silvio Ribeiro da; PACHECO, Cinthia Alencar. Currículo do Ensino de Língua Inglesa e uso de tecnologias digitais previstos na BNCC. Revista Eletrônica de Educação, São Carlos, v. 14, p. 1-17, jan./dez. 2020.

THEWES, Jéssica Daiana Levandovski; STEYER, Daiana; FRONZA, Cátia de Azevedo. Reflexões sobre letramento crítico nas aulas de língua estrangeira a partir de perspectiva trazida pela Base Nacional Comum Curricular. Revista do GELNE, Natal, v. 22, n. 1, p. 188-202, 2020.

Revista de Estudios Teóricos y Epistemológicos en Política Educativa, v. 6, e2118101, p. 1-38, 2021 Disponible en: <https://www.revistas2.uepg.br/index.php/retepe> 


\section{LÍNGUA INGLESA - Teses e Dissertações \\ Total: 2}

FORTES, Olívia Bueno Silva. Neoliberalismo e a educação contemporânea: professores de inglês entre a criticidade, a neutralidade e a censura. 2019. Dissertação (Mestrado em Educação) - Universidade de São Paulo, São Paulo, 2019.

SANTOS, Aline Kieling Juliano Honorato. Projeto político curricular de Letras Inglês da UFAC e a Base Nacional Comum Curricular: possíveis conexões dialógicas para o uso das tecnologias digitais. 2019. Dissertação (Mestrado em Letras- Linguagem e Identidade) - Universidade Federal do Acre, Rio Branco, 2019.

Fonte: Dados da pesquisa organizados pelo autor.

Quadro 16 - Trabalhos sobre BNCC vinculados à categoria Sociologia

\section{SOCIOLOGIA - Artigos Total: 4}

BODART, Cristiano das Neves; FEIJÓ, Fernanda. As Ciências Sociais no Currículo do Ensino Médio brasileiro. Espaço do Currículo (online), João Pessoa, v. 13, n. 2, p. 219-234, maio/ago. 2020.

MEDEIROS, Emerson Augusto de; MENEZES, Maria Alcinete Gomes de. Educação do campo: estudo sobre a Base Nacional Comum Curricular a partir de percepções de professores/as da área de ciências humanas. Revista Cocar, Belém, v. 14, n. 28, p. 17-32, jan./abr. 2020.

SILVA, Ileizi Fiorelli; ALVES NETO, Henrique Fernandes. O Processo de Elaboração da Base Nacional Comum Curricular (BNCC) no Brasil e a Sociologia (2014 a 2018). Espaço do Currículo (online), João Pessoa, v. 13, n. 2 , p. 262-284, maio/ago. 2020.

SILVA, Lady Daiana Oliveira da; MOREIRA, Núbia Regina. O Currículo de Sociologia e a luta política pela diversidade étnico-racial no Ensino Médio: BNCC. e-Curriculum, São Paulo, v. 18, n. 4, p. 1915-1933, 2020.

Fonte: Dados da pesquisa organizados pelo autor.

Quadro 17 - Trabalhos sobre BNCC vinculados à categoria Química

\section{QUÍMICA - Artigos Total: 3}

PRADO, Leticia do; RAVARES, Fabio Daniel. Energia no dia a dia: análise de uma sequência didática ministrada no Ensino Médio. Revista Thema, Pelotas, v. 17, p. 658-674, 2020.

ROSA, Anderson da Silva; ROEHRS, Rafael. Aplicativos móveis: algumas possibilidades para o ensino de Química. Research, Society and Development, Itajaí, v. 9, n. 8, p. 1-27, 2020.

SANTOS, Diego Marlon; NAGASHIMA, Lucia Akiko. A Base Nacional Comum Curricular: a reforma do ensino médio e a organização da disciplina de química. Pedagogia em Foco, Iturama, v. 12, n. 7, p. 175-191, jan./jun. 2017.

\section{QUÍMICA - Teses e Dissertações Total: 1}

SOUZA, Raquel Oliveira de. Das coisas da Química à Química das coisas: uma proposta investigativa para o componente curricular química. 2019. Dissertação (Mestrado em Ensino de Ciências) - Universidade de Brasília, Brasília, 2019.

Fonte: Dados da pesquisa organizados pelo autor.

Quadro 18 - Trabalhos sobre BNCC vinculados à categoria Filosofia

\section{FILOSOFIA - Artigos}

\section{Total: 3}

CONCEIÇÃO, Thiago Gruner. Que interdisciplinaridade a BNCC oferece à Filosofia? aproximações à língua portuguesa. REFilo - Revista Digital de Ensino de Filosofia, Santa Maria, v. 6, p. 1-10, 2020. 
GOYANNA FILHO, Eduardo Vasconcelos; ANDRADE, Adriano Bittencourt. Filosofia no ensino médio: a integração escolauniversidade e o uso de cadeias exemplificativas para acessibilizar a linguagem filosófica. Revista Brasileira do Ensino Médio, Ipojuca, v. 3, p. 120-130, 2020.

HEUSER, Ester Maria Dreher; DIAS, Adriana Muniz. Raspas e restos de Filosofia na BNCC - EM: trampolim para uma ética como experimentação. Teias, Rio de Janeiro, v. 21, n. 63, p. 123-134, out./dez. 2020.

Fonte: Dados da pesquisa organizados pelo autor.

Quadro 19 - Trabalhos sobre BNCC vinculados à categoria Física

\section{FÍSICA - Artigos}

Total: 2

CALADO, Henrique Carvalho; PETRUCCI-ROSA, Maria Inês. Formação de professores de Física e interdisciplinaridade: episódios de refração de políticas em narrativas de reforma curricular. Ciência \& Educação, Bauru, v. 25, n. 2, p. 525-538, abr./jun. 2019.

LOPES, Arivaldo; ARAÚJO, Mauro Sérgio Teixeira de. Identificação de competências da Base Nacional Comum Curricular (BNCC) no Ensino Médio. Revista de Ensino de Ciências e Matemática - REnCiMa, São Paulo, v. 11, n. 5, p. 94-113, 2020.

Fonte: Dados da pesquisa organizados pelo autor.

Quadro 20 - Trabalhos sobre BNCC vinculados à categoria Estágio

\section{ESTÁGIO - Artigos Total: 1}

SILVA, Claudionor Renato da. A BNCC em três apontamentos para estagiários(as) na Educação Infantil - estágio em pesquisa. Movimento - Revista de Educação, Rio de Janeiro, ano 6, n. 10, p. 121-146, jan./jun. 2019.

Fonte: Dados da pesquisa organizados pelo autor.

\section{Considerações finais}

Este texto teve por objetivo apresentar o levantamento sobre a produção de conhecimento no Brasil referente à BNCC, quer em caráter de artigos científicos acessíveis por diversos indexadores que hospedam as produções publicadas por revistas científicas, ou em caráter de teses e dissertações indexadas em plataformas que hospedam as produções dos Programas de PósGraduação das universidades brasileiras.

A apresentação conferiu ênfase à categorização possível dessas publicações. O levantamento indica, até o momento, a possibilidade de organizar as publicações a partir de 20 categorias, amplamente vinculadas aos denominados componentes curriculares - Português, Matemática, Química, Física, entre outros -, tendo apenas quatro categorias vinculadas a outras temáticas, a saber: Educação Ambiental, Gênero e Sexualidade, Alfabetização-Letramento e Estágio.

O levantamento explicita um visível apego do exercício de produção de conhecimento sobre a BNCC como Política curricular, seguida de sua relação com a Língua Portuguesas e a Matemática. Essas três categorias concentram 322 publicações do total das 602 identificadas, resultando em mais da metade da produção de conhecimento sobre a BNCC no Brasil.

Considerando as temáticas movimentadas no conjunto das produções, é possível reconhecer uma amplitude de abordagens, que indicam o alcance da BNCC no âmbito da política educacional em dialogar com áreas como política de formação de professores, política de avaliação e política de gestão da educação, bem como com todas as etapas da Educação Básica - Educação Infantil, Ensino Fundamental e Ensino Médio. 
Destaca-se, ainda, que as publicações apresentam ampla contribuição para o debate sobre os fundamentos político-pedagógicos, didáticos, tecnológicos e metodológicos da educação e marcada ausência, parcial ou total, de produções sobre campos e temáticas, tais como: Educação em Direitos Humanos, Educação Inclusiva e Educação para Relações Étnico-Raciais.

As características do conjunto das publicações organizadas no levantamento possibilitam indicar como objeto de continuidade e aprofundamento das pesquisas sobre a BNCC, além da Educação em Direitos Humanos, Educação Inclusiva e Relações Étnico-Raciais, os processos de implementação dessa política, seu impacto nas práticas educativas e as leituras e as experiências da comunidade educativa sobre a BNCC.

\section{Referências}

BRASIL. [Constituição (1988)]. Constituição da República Federativa do Brasil. Brasília, DF: Senado, 1988.

BRASIL. Lei No 9.394, de 20 de dezembro de 1996. Estabelece as diretrizes e bases da educação nacional. Diário Oficial da União: seção 1, Brasília, DF, n. 248, p. 27833-27841, 23 dez. 1996.

BRASIL. Lei No 13.005, de 25 de junho de 2014. Aprova o Plano Nacional de Educação - PNE e dá outras providências. Diário Oficial da União: seção 1, Brasilia, DF, n. 120-A, edição extra, p. 1-7, 26 jun. 2014.

BRASIL. Resolução CNE/CP Nº 2, de 22 de dezembro de 2017. Institui e orienta a implantação da Base Nacional Comum Curricular, a ser respeitada obrigatoriamente ao longo das etapas e respectivas modalidades no âmbito da Educação Básica. Diário Oficial da União: seção 1, Brasília, DF, n. 245, p. 41-44, 22 dez. 2017.

BRASIL. Resolução Nº 4, de 17 de dezembro de 2018. Institui a Base Nacional Comum Curricular na Etapa do Ensino Médio (BNCC-EM), como etapa final da Educação Básica, nos termos do artigo 35 da LDB, completando o conjunto constituído pela BNCC da Educação Infantil e do Ensino Fundamental, com base na Resolução CNE/CP n ${ }^{\circ} 2 / 2017$, fundamentada no Parecer CNE/CP n ${ }^{\circ}$ 15/2017. Diário Oficial da União: seção 1, Brasília, DF, n. 242, p. 120, 18 dez. 2018.

MAINARDES, J. Metapesquisa no campo da política educacional: elementos conceituais. Educar em Revista, Curitiba, v. 34, n. 72, p. 303-319, nov./dez. 2018. DOI: https://doi.org/10.1590/0104-4060.59762

MAINARDES, J. A metapesquisa no campo da Política Educacional: aspectos teóricos, conceituais e metodológicos. In: MAINARDES, J. Metapesquisa no campo Política Educacional. Curitiba: CRV, 2021. p. 19-43.

MAINARDES, J.; TELLO, C. A pesquisa no campo da Política Educacional: explorando diferentes níveis de abordagem e abstração. Archivos Analíticos de Políticas Educativas, [s. l.], v. 24, n. 75, p. 1-17, jul. 2016. DOI: http://dx.doi.org/10.14507/epaa.24.2331

TELLO, C.; MAINARDES, J. Revisitando o enfoque das epistemologias da Política Educacional. Práxis Educativa, Ponta Grossa, v. 10, n. 1, p. 153-178, jan./jun. 2015. DOI: https://doi.org/10.5212/PraxEduc.v.10i1.0007 
A produção de conhecimento sobre a Base Nacional Comum Curricular no Brasil: levantamento...

TELLO, C. G. Las epistemologías de la política educativa: vigilancia y posicionamiento epistemológico del investigador en política educativa. Práxis Educativa, Ponta Grossa, v. 7, n. 1, p. 53-68, jan./jun. 2012. DOI: https://doi.org/10.5212/praxeduc.v.7i1.0003

Recebido em 10/03/2021

Versão corrigida recebida em 28/05/2021

Aceito em 30/05/2021

Publicado online em 07/06/2021

Revista de Estudios Teóricos y Epistemológicos en Política Educativa, v. 6, e2118101, p. 1-38, 2021 Disponible en: <https://www.revistas2.uepg.br/index.php/retepe> 